\title{
Geochemical Assessment of the Hueco Bolson, New Mexico and Texas, 2016-17
}

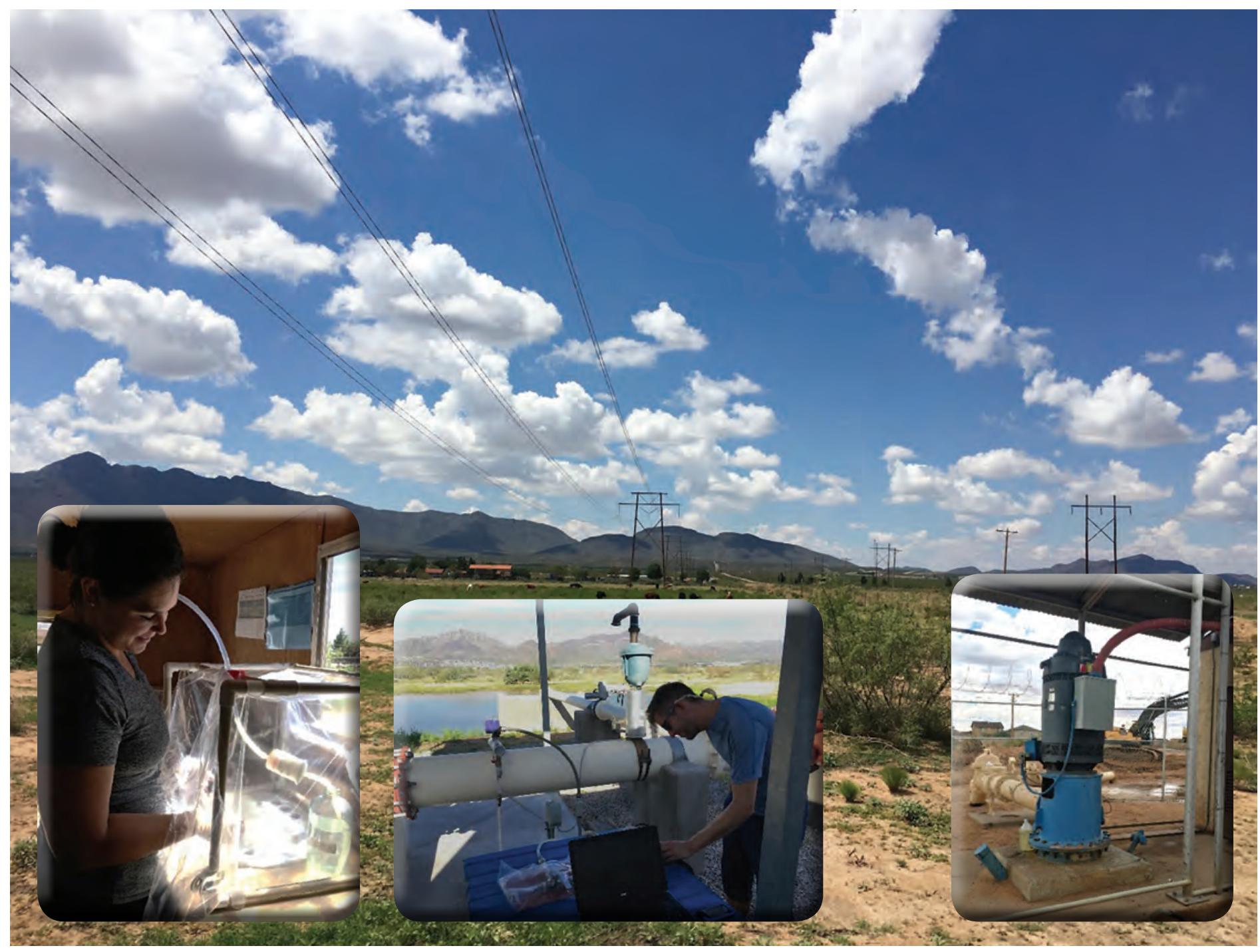

Scientific Investigations Report 2020-5056 


\section{Front cover.}

Background. Franklin Mountains near the Hueco Bolson study area near El Paso, Texas, September 2016. Photograph by Monica Langhorst, U.S. Geological Survey.

Lower left. U.S. Geological Survey scientist collecting water-quality samples in the Hueco Bolson study area near El Paso, Texas, September 2016. Photograph by Chris Braun, U.S. Geological Survey.

Lower middle. U.S. Geological Survey scientist assessing the physical properties of water before sample collection from a groundwater well in the Hueco Bolson study area near El Paso, Texas, September 2016. Photograph by Monica Langhorst, U.S. Geological Survey.

Lower right. Groundwater well sampled in the Hueco Bolson study area near El Paso, Texas, September 2016. Photograph by Chris Braun, U.S. Geological Survey.

Back cover. U.S. Geological Survey field sampling crew arriving at a groundwater well that was sampled in the Hueco Bolson study area near El Paso, Texas, September 2016. Photograph by Chris Braun, U.S. Geological Survey. 


\section{Geochemical Assessment of the Hueco Bolson, New Mexico and Texas, 2016-17}

By Patricia B. Ging, Delbert G. Humberson, and Scott J. Ikard

Scientific Investigations Report 2020-5056 


\title{
U.S. Department of the Interior \\ DAVID BERNHARDT, Secretary
}

\author{
U.S. Geological Survey \\ James F. Reilly II, Director
}

U.S. Geological Survey, Reston, Virginia: 2020

For more information on the USGS - the Federal source for science about the Earth, its natural and living resources, natural hazards, and the environment—visit https://www.usgs.gov or call 1-888-ASK-USGS.

For an overview of USGS information products, including maps, imagery, and publications, visit https://store.usgs.gov/.

Any use of trade, firm, or product names is for descriptive purposes only and does not imply endorsement by the U.S. Government.

Although this information product, for the most part, is in the public domain, it also may contain copyrighted materials as noted in the text. Permission to reproduce copyrighted items must be secured from the copyright owner.

Suggested citation:

Ging, P.B., Humberson, D.G., and Ikard, S.J., 2020, Geochemical assessment of the Hueco Bolson, New Mexico and Texas, 2016-17: U.S. Geological Survey Scientific Investigations Report 2020-5056, 30 p., https://doi.org/10.3133/ sir20205056.

ISSN 2328-031X (print)

ISSN 2328-0328 (online) 


\section{Acknowledgments}

Access and sampling of the water-supply wells would not have been possible without the collaboration and permission of personnel from El Paso Water and Fort Bliss. Eric Bangs with El

Paso Water and Rita Crites with Fort Bliss assisted with selecting wells to sample. 



\section{Contents}

Acknowledgments ……...................................................................................................................

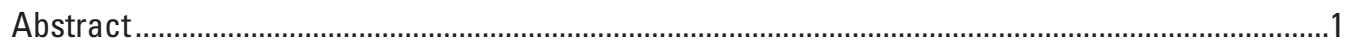

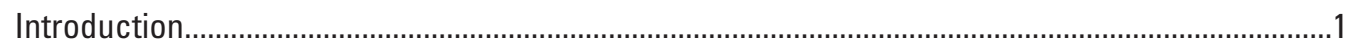

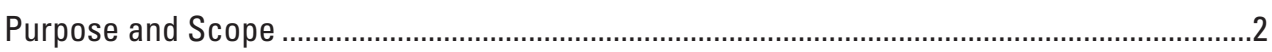

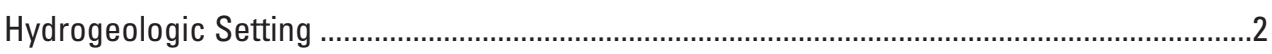

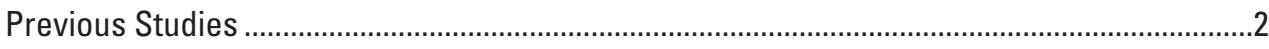

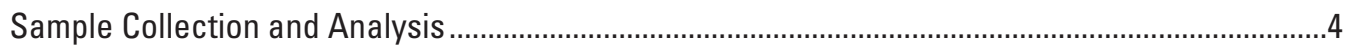

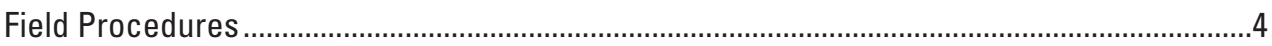

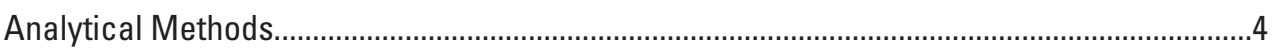

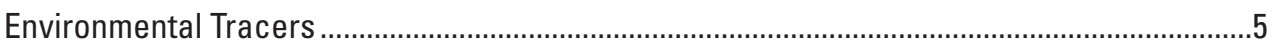

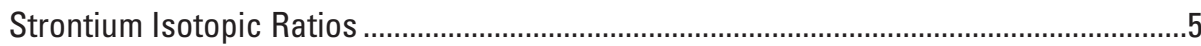

Hydrogen and Oxygen Isotopic Ratios ..........................................................................

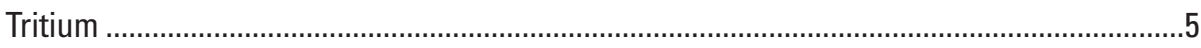

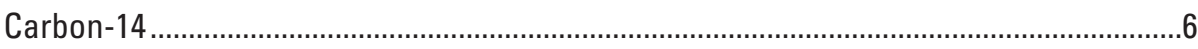

Quality-Assurance and Quality-Control Procedures .............................................................

Field-Blank Analyses.................................................................................................

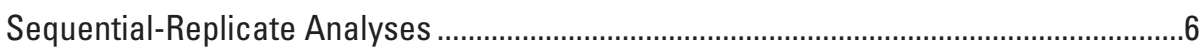

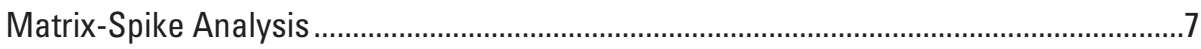

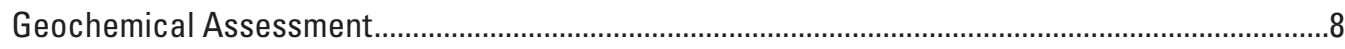

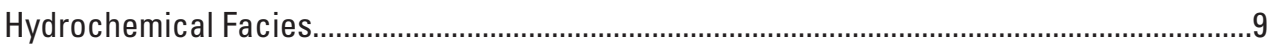

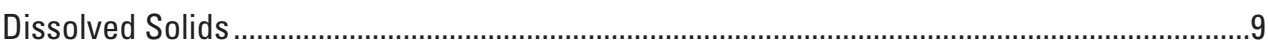

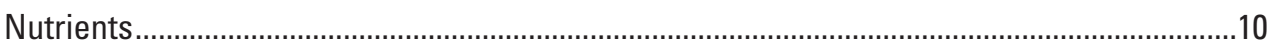

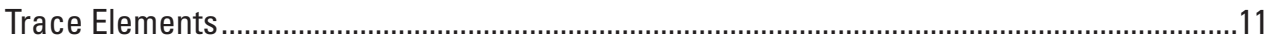

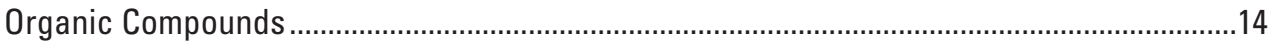

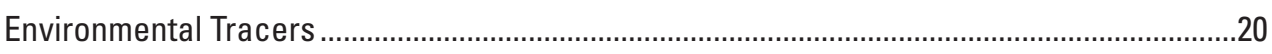

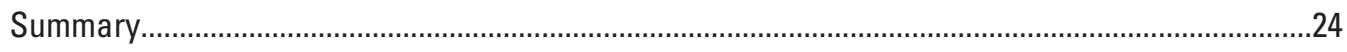

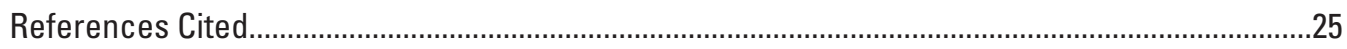

\section{Figures}

1. Map showing the Hueco Bolson study area, New Mexico and Texas, United States, and Mexico, 2016-17 ......................................................................................

2. Map showing land use in the Hueco Bolson study area in New Mexico and Texas, with locations of wells sampled in 2016 or 2017 ...................................................8

3. Trilinear diagram depicting the relative abundance of major cations and anions in groundwater samples collected in New Mexico and Texas in the Hueco Bolson study area and identification of sodium-chloride type waters, 2016-17 .............10

4. Graphs showing dissolved-solids concentrations measured in samples collected from wells in New Mexico and Texas in the Hueco Bolson study area during 2016-17: numbers of samples containing specified ranges of dissolved-solids concentrations, and relation between dissolved-solids concentration and well depth. 
5. Map showing concentrations of dissolved solids measured in groundwater samples collected from wells in New Mexico and Texas in the Hueco Bolson study area, 2016-17

6. Graphs showing concentrations of dissolved solids and sodium and chloride and sodium measured in groundwater samples collected from wells in New Mexico and Texas in the Hueco Bolson study area, 2016-17.

7. Graphs showing nitrate concentrations measured in samples collected from wells in New Mexico and Texas in the Hueco Bolson study area during 2016-17: numbers of samples containing specified ranges of nitrate concentrations, and relation between nitrate concentration and dissolved-oxygen concentration

8. Map showing concentrations of arsenic measured in groundwater samples collected from wells in New Mexico and Texas in the Hueco Bolson study area, 2016-17

9. Map showing concentrations of uranium measured in groundwater samples collected from wells in New Mexico and Texas in the Hueco Bolson study area, 2016-17.

10. Map showing wells with detections of organic compounds in groundwater samples in New Mexico and Texas in the Hueco Bolson study area, 2016-17

11. Map showing strontium-87 to strontium-86 ratios in groundwater samples collected from wells in New Mexico and Texas in the Hueco Bolson study area, 2016-17

12. Graph showing the ratio of oxygen-18 to oxygen-16 (delta oxygen-18) and the ratio of hydrogen-2 to hydrogen-1 (delta deuterium) measured in samples collected from wells in New Mexico and Texas in the Hueco Bolson study area, 2016-17; and graph showing the ratio of oxygen-18 to oxygen-16 (delta oxygen-18) and the ratio of hydrogen-2 to hydrogen-1 (delta deuterium) as reported in previous studies describing groundwater samples collected in the southwestern Hueco Bolson...

13. Graph showing carbon-14 and tritium concentrations, with apparent age designations for groundwater samples collected from wells in New Mexico and Texas in the Hueco Bolson study area, 2016-17.

14. Map showing relative groundwater ages for groundwater samples collected from wells in New Mexico and Texas in the Hueco Bolson study area, 2016-17

\section{Tables}

1. Wells sampled in New Mexico and Texas in the Hueco Bolson study area, 2016-17....11

2. Trace elements detected in groundwater samples collected from wells in New Mexico and Texas in the Hueco Bolson study area, with U.S. Environmental Protection Agency designated drinking-water standards for trace elements, and percentage of wells where the collected samples exceeded the standard for selected trace elements, 2016-17. 


\section{Conversion Factors}

U.S. customary units to International System of Units

\begin{tabular}{|c|c|c|}
\hline Multiply & By & To obtain \\
\hline \multicolumn{3}{|c|}{ Length } \\
\hline foot $(\mathrm{ft})$ & 0.3048 & meter $(\mathrm{m})$ \\
\hline mile (mi) & 1.609 & kilometer (km) \\
\hline \multicolumn{3}{|c|}{ Radioactivity } \\
\hline picocurie per liter $(\mathrm{pCi} / \mathrm{L})$ & 0.037 & becquerel per liter $(\mathrm{Bq} / \mathrm{L})$ \\
\hline
\end{tabular}

International System of Units to U.S. customary units

\begin{tabular}{lcl}
\hline \multicolumn{1}{c}{ Multiply } & By & \multicolumn{1}{c}{ To obtain } \\
\hline meter $(\mathrm{m})$ & Length & \\
kilometer $(\mathrm{km})$ & 3.281 & foot $(\mathrm{ft})$ \\
kilometer $(\mathrm{km})$ & 0.6214 & mile $(\mathrm{mi})$ \\
meter $(\mathrm{m})$ & 0.5400 & mile, nautical $(\mathrm{nmi})$ \\
& 1.094 & yard $(\mathrm{yd})$ \\
\hline square meter $\left(\mathrm{m}^{2}\right)$ & Area & \\
square kilometer $\left(\mathrm{km}^{2}\right)$ & 0.0002471 & acre \\
square meter $\left(\mathrm{m}^{2}\right)$ & 247.1 & acre \\
square kilometer $\left(\mathrm{km}^{2}\right)$ & 10.76 & square foot $\left(\mathrm{ft}^{2}\right)$ \\
\hline
\end{tabular}

Temperature in degrees Celsius $\left({ }^{\circ} \mathrm{C}\right)$ may be converted to degrees Fahrenheit $\left({ }^{\circ} \mathrm{F}\right)$ as ${ }^{\circ} \mathrm{F}=(1.8 \times$ $\left.{ }^{\circ} \mathrm{C}\right)+32$.

Temperature in degrees Fahrenheit $\left({ }^{\circ} \mathrm{F}\right)$ may be converted to degrees Celsius $\left({ }^{\circ} \mathrm{C}\right)$ as ${ }^{\circ} \mathrm{C}=\left({ }^{\circ} \mathrm{F}-\right.$ 32) / 1.8 .

\section{Datum}

Vertical coordinate information is referenced to the North American Vertical Datum of 1988 (NAVD 88).

Horizontal coordinate information is referenced to the North American Datum of 1983 (NAD 83).

Altitude, as used in this report, refers to distance above the vertical datum.

\section{Supplemental Information}

Concentrations of chemical constituents in water are given in either milligrams per liter (mg/L) or micrograms per liter $(\mu \mathrm{g} / \mathrm{L})$.

Activities for radioactive constituents in water are given in picocuries per liter (pCi/L). 


\section{Abbreviations}

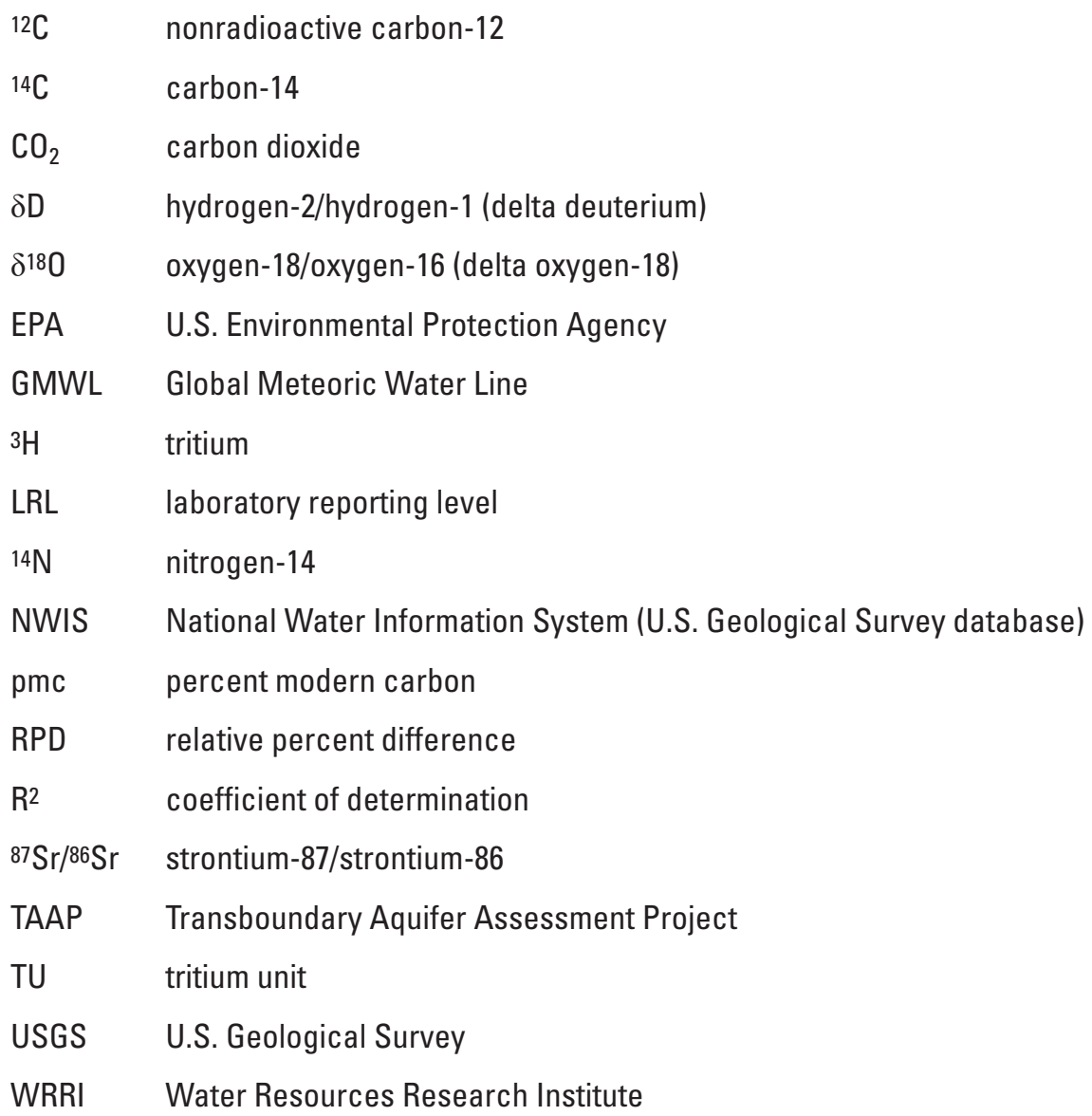




\title{
Geochemical Assessment of the Hueco Bolson, New Mexico and Texas, 2016-17
}

\author{
By Patricia B. Ging, Delbert G. Humberson, and Scott J. Ikard
}

\section{Abstract}

Understanding groundwater quality in transboundary aquifers like the Hueco Bolson is important for the 2.7 million people along the United States and Mexico border living in and near the combined metropolitan areas of Ciudad Juárez, Mexico, and El Paso, Texas, who rely on groundwater for water supply. To better understand water-quality conditions in the Mexico-New Mexico-Texas transboundary area, 23 water-supply wells were sampled in the Hueco Bolson within the United States near El Paso, Tex., during AugustSeptember 2016 and May-June 2017. Groundwater samples were analyzed for physical properties, major ions, dissolved solids, nutrients, trace elements, organic compounds, and selected isotopes such as strontium, hydrogen, oxygen, tritium, and carbon-14.

Most of the water samples from the Hueco Bolson watersupply wells were classified as a sodium-chloride type water. Only four wells sampled in the study area had dissolved-solids concentrations greater than 1,000 milligrams per liter (mg/L), with three of those wells closest to the Rio Grande/Río Bravo del Norte (hereinafter referred to as the Rio Grande).

Nitrate concentrations in the groundwater samples collected in the study area ranged from below the long-term method detection level of 0.04 to $6.2 \mathrm{mg} / \mathrm{L}$. Arsenic was the only trace element detected in the wells sampled that had concentrations exceeding the designated drinking-water standard of 10 micrograms per liter $(\mu \mathrm{g} / \mathrm{L})$. Four of the 23 wells had arsenic concentrations greater than $10 \mu \mathrm{g} / \mathrm{L}$, and these wells were all located near the Rio Grande. Three of the wells with the highest uranium concentrations (greater than $10 \mu \mathrm{g} / \mathrm{L}$ ) were also located near the Rio Grande, and two of those wells were the same wells that had arsenic concentrations greater than $10 \mu \mathrm{g} / \mathrm{L}$. Groundwater samples were analyzed for 83 organic compounds, but only 6 were detected - simazine, prometryn, prometon, atrazine, deethylatrazine, and dichloroaniline. All concentrations for the organic compounds detected were less than $0.03 \mu \mathrm{g} / \mathrm{L}$, and the detections were only in five groundwater wells, three of which were located near the Rio Grande.

Strontium, hydrogen, and oxygen isotopic values indicate that recharge water to the central and northern sections of the study area originates from near the Franklin Mountains, whereas groundwater in the southern section of the study area is likely from the Rio Grande valley. Tritium and carbon-14 values indicate that most of the wells that were sampled contained water that is considered premodern, which means that it is more than several hundred years old. Three wells with modern groundwater (approximately less than 70 years old) are located near the Rio Grande and are the same wells that had elevated arsenic or uranium concentrations and organic compound detections. Most of the results of the geochemical analyses indicate that groundwater near the Rio Grande has higher dissolved-solids concentrations, higher concentrations of several trace elements, and slightly more organic compound detections than the groundwater farther away from the Rio Grande; therefore, the groundwater may be affected by the Rio Grande and surrounding land-use activities.

\section{Introduction}

Many communities along the United States and Mexico border rely partially or completely on transboundary aquifers underlying parts of each country for drinking-water, agricultural, and industrial-water supply needs. Little geochemical information is available to help characterize this vital resource (Alley, 2013). Because surface water is scarce along the United States and Mexico border and typically fully appropriated, groundwater from transboundary aquifers is crucial for public supply (Alley, 2013). Among the unique challenges in assessing transboundary aquifers is the ability to provide useful information on the quality of usable water available to meet the diverse needs of residents along the border. Addressing this challenge is critical to provide a foundation for resource management. Some common physical and socioeconomic characteristics shared across the border region between Mexico and the United States near Ciudad Juárez, Mexico, and El Paso, Texas, include a semiarid climate with little precipitation and large population centers. The combined 2014 population of about 2.7 million in Ciudad Juárez, Mexico, and El Paso, Tex., form the second largest metropolitan area on the Mexico-United States border (National Aeronautics and Space Administration, 2014). 
The U.S.-Mexico Transboundary Aquifer Assessment Act (hereinafter referred to as "the act") was signed into law by the President of the United States in 2006 (Public Law 109-448).

The U.S.-Mexico Transboundary Aquifer Assessment Program (TAAP) was established as part of the act to develop and implement an integrated scientific approach to identify and assess priority transboundary aquifers. The area designated by the act includes transboundary aquifers shared between the States of Sonora and Chihuahua in Mexico and the States of Arizona, New Mexico, and Texas in the United States. TAAP collaborators include the U.S. Geological Survey (USGS) Water Science Centers and the Water Resources Research Institutes (WRRIs) of Arizona, New Mexico, and Texas. One of the goals of this act is to complete regional hydrogeologic studies of priority transboundary aquifers in groundwaterdependent border communities subject to stress from development and drought. The regional studies developed under this act were aimed at providing information on groundwater resources in the priority areas. One of the priority aquifer regions stipulated in the act was the Hueco Bolson in New Mexico and Texas. A bolson is an alluvium-floored basin found in arid terrain in northern Mexico and the southwestern United States into which water drains from surrounding mountains (Neuendorf and others, 2005). Understanding the geochemical characteristics of the Hueco Bolson is necessary in developing a plan for long-term management of this groundwater resource.

\section{Purpose and Scope}

The purpose of this report is to present the results of analyses of water-quality samples collected in 2016 and 2017 from 23 water-supply wells in a part of the Hueco Bolson; the wells that were sampled were geospatially distributed in New Mexico and Texas near Ciudad Juárez, Mexico, and El Paso, Tex. Water-quality samples from these wells, which belong to Fort Bliss and El Paso Water, were analyzed for major ions, trace elements, nutrients, organic compounds, and selected isotopes (strontium, deuterium, oxygen, tritium, and carbon). Geochemical interpretations of these data were made to provide insights into groundwater quality, sources, and age. Groundwater samples could be not collected in Mexico because of lack of access to that part of the Hueco Bolson; therefore, all water-quality samples were collected in the U.S. part of the Hueco Bolson.

\section{Hydrogeologic Setting}

The Hueco Bolson is part of the Hueco-Mesilla Bolsons aquifer and spans a total area of approximately 6,500 square kilometers that includes parts of New Mexico and Texas in the United States and Chihuahua in Mexico (Heywood and Yager, 2003; Hutchison and Hibbs, 2008; George and others, 2011). The Hueco Bolson is bounded by several mountain ranges including the Franklin and Sierra Juárez Mountains to the west and the Hueco, Sierra Blanca, and Quitman Mountains to the east (White, 1983; Hibbs, 1999; Sheng, 2005; Hutchison and Hibbs, 2008). To the north, the Hueco Bolson is bounded by the Tularosa Basin in New Mexico; the Tularosa Basin is hydraulically connected to the Hueco Bolson (Wilkins, 1986; Heywood and Yager, 2003; Hutchison and Hibbs, 2008; fig. 1). The Hueco Bolson is considered an intermontane aquifer that is associated with the Rio Grande Rift, which was formed as a result of Cenozoic extensional tectonism that created a horst and graben geological structure (Hutchison, 2006). Over time, the down-dropped graben filled with unconsolidated Tertiary and Quaternary deposits of gravel, sand, silt, and clay that were eroded from the surrounding highlands which may include volcanic rock (White and others, 1997; Heywood and Yager, 2003). These deposits resulted in the alluvial-aquifer region currently known as the Hueco Bolson, which has a maximum thickness of 2,743 meters (White, 1983; Heywood and Yager, 2003; Sheng, 2005). The Rio Grande/Río Bravo or Río Bravo del Norte (hereinafter referred to as the Rio Grande) is the major surface-water feature in the study area and has eroded a valley through the basin-fill deposits of the Hueco Bolson (White and others, 1997).

The Hueco Bolson has been known as a good source of freshwater since the late 1800 s and has become the primary source of fresh groundwater for drinking water and for agricultural and industrial use in the rapidly growing transboundary region near Ciudad Juárez, Mexico, and El Paso, Tex. (White, 1983; White and others, 1997; Hibbs, 1999). By the end of the 20th century, the total binational population in the El Paso metropolitan area (including Ciudad Juárez) had grown to approximately 2 million (Heywood and Yager, 2003); as the population grew, groundwater pumping increased over time (White, 1983). Total groundwater drawdown was observed to exceed 60 meters in some areas (Heywood and Yager, 2003), and the increased pumping has led to concerns with brackish water intrusion-in some cases water-supply wells have even been abandoned because of deteriorating water quality (Heywood and Yager, 2003; Hutchison, 2006). In this report, dissolved-solids concentrations less than or equal to 1,000 milligrams per liter $(\mathrm{mg} / \mathrm{L})$ are considered indicative of freshwater, whereas dissolved-solids concentrations greater than 1,000 $\mathrm{mg} / \mathrm{L}$ and less than $10,000 \mathrm{mg} / \mathrm{L}$ are considered indicative of brackish water. Groundwater management in the area is centered on the interrelated issues of declining groundwater levels and brackish groundwater intrusion (Hutchison, 2006).

\section{Previous Studies}

Most of the previous studies done in the Hueco Bolson near the Ciudad Juárez, Mexico, and El Paso, Tex., area focused on hydrogeology and groundwater flow, especially near Fort Bliss (Abeyta, 1996; Abeyta and Thomas, 1996; Frenzel and Abeyta, 1999). Orr and Risser (1992) summarize previous studies regarding hydrologic data in the Ciudad Juárez/El Paso region of the Hueco Bolson. Few reports 


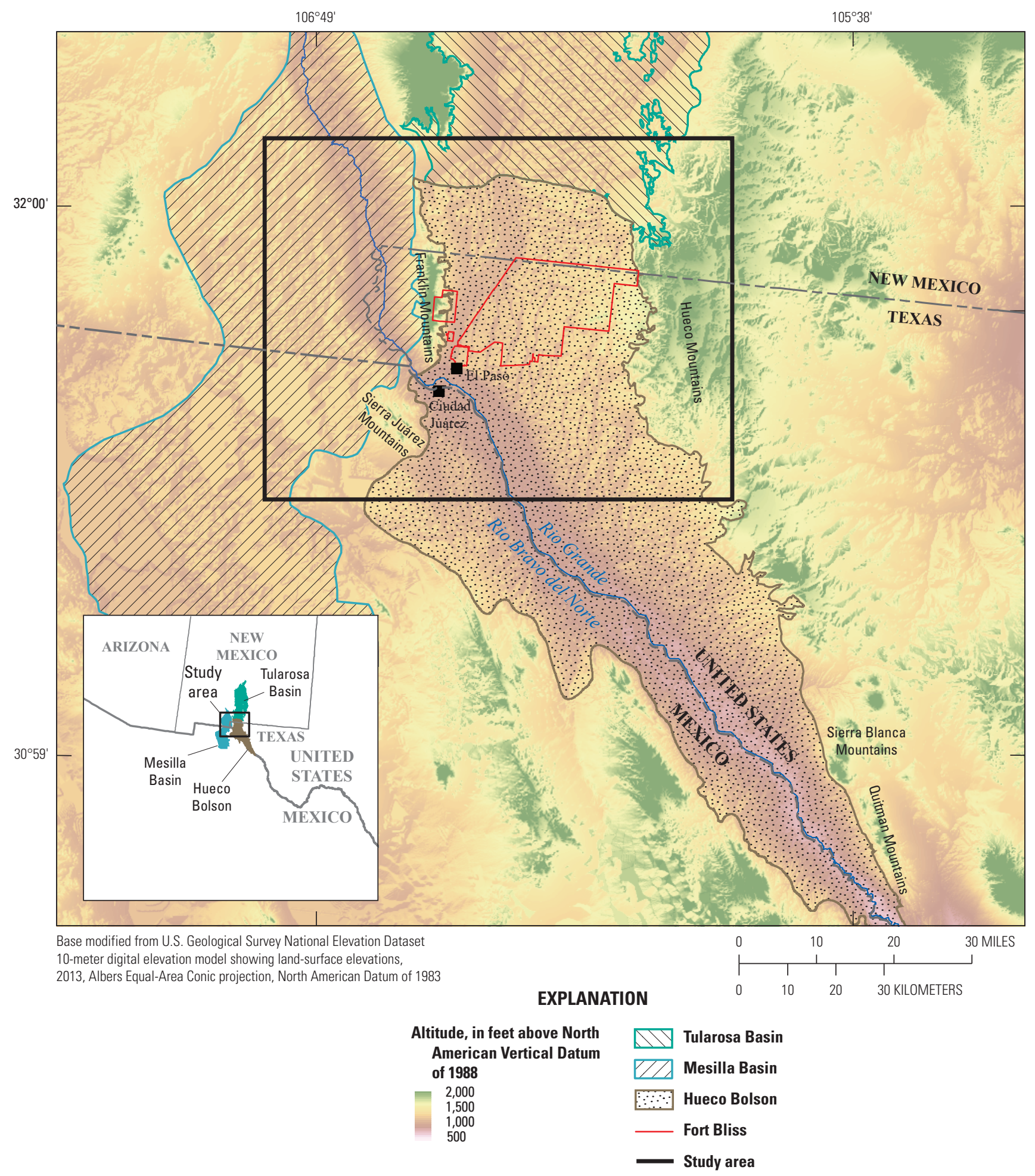

Figure 1. The Hueco Bolson study area, New Mexico and Texas, United States, and Mexico, 2016-17.

discuss geochemistry or water quality in the Ciudad Juárez/ El Paso region of the Hueco Bolson. Buszka and others (1994) discuss selected water-quality aspects of the Hueco Bolson near the Hueco Bolson Recharge Project Area near Ciudad Juárez, Mexico, and El Paso, Tex., where groundwater samples were collected near the recharge project site in 1990 and analyzed for major ions, trace elements, nutrients, dissolved organic carbon, volatile organic compounds, semivolatile organic compounds, bacteria, and stable-isotopic ratios of oxygen, hydrogen, and carbon. Results indicated that 
the principal source of recharge to the aquifer by humans is reclaimed water injection. Anderholm and Heywood (2003) discuss groundwater chemistry in the southwestern part of the Hueco Bolson in a study area similar to the one described in this report. Groundwater samples in the Anderholm and Heywood study were analyzed for major ions, nutrients, total organic carbon, trace elements, and stable and radioactive isotopes. Results indicated that infiltration of precipitation and runoff from the Franklin Mountains and leakage from the Rio Grande Valley are important sources of recharge to the Hueco Bolson. In addition, isotopic and environmental tracer analysis results along the Rio Grande and in the Hueco Bolson were reported by Phillips and others (2003) and Eastoe and others (2008) who distinguished different recharge areas based on the results of deuterium and oxygen isotopes in waterquality samples.

\section{Sample Collection and Analysis}

During August and September 2016, 20 water-supply wells were sampled in the western part of Texas just east of the Franklin Mountains as part of the geochemical assessment of the Hueco Bolson (fig. 2). In May and June 2017, three additional water-supply wells were sampled - one well in the northern section of the Hueco Bolson and two wells north of the Hueco Bolson in the southern part of New Mexico. Physical properties (dissolved oxygen, $\mathrm{pH}$, specific conductance, water temperature, turbidity, and alkalinity) along with barometric pressure, groundwater pumping rates, and depth to water were measured in the field at the time of sample collection. Water samples were collected and shipped for laboratory analysis of major ions, nutrients, trace elements, organic compounds, and stable isotope ratios of strontium (strontium-87/ strontium-86, ${ }^{87} \mathrm{Sr} / 86 \mathrm{Sr}$ ), hydrogen (hydrogen-2/hydrogen-1, $\delta \mathrm{D}$ ), oxygen (oxygen-18/oxygen-16, $\delta^{18} \mathrm{O}$ ), tritium $\left({ }^{3} \mathrm{H}\right)$, and carbon-14 $\left({ }^{14} \mathrm{C}\right)$. All water-quality results were reviewed for completeness and accuracy and are stored in the National Water Information System (NWIS) (USGS, 2019) and are also published in a companion data release (Ging and others, 2019).

\section{Field Procedures}

The field procedures used to collect groundwater samples are described in the USGS "National Field Manual for the Collection of Water-Quality Data" (USGS, variously dated). All wells sampled were water-supply wells with pumps already installed that were used to purge the water and to collect the water-quality samples. Prior to sample collection, each well was pumped until one to three casing volumes were purged to remove any stagnant water. The number of casing volumes that were purged depended on depth of the well, well casing diameter, and the frequency of pumping performed at the well. After the required one to three casing volumes were purged, the wells were pumped continually until steady-state measurements for all physical properties were obtained to ensure representative samples of the water in aquifer were collected (USGS, variously dated). When steady-state measurements indicating the system had reached equilibrium were obtained, the water samples were collected from the well through fluoropolymer tubing and stored in new, precleaned bottles. Samples were collected prior to well water entering any pressure tanks or being filtered or undergoing other forms of treatment. Samples were processed onsite according to each laboratory's protocols to minimize chemical changes or contamination. In addition, samples were preserved by adding the appropriate acid (when necessary), chilled to 4 degrees Celsius $\left({ }^{\circ} \mathrm{C}\right)$, or both before being shipped to the laboratory for analysis. Time-sensitive samples were shipped overnight to the analyzing laboratories, and the remaining samples were shipped to the analyzing laboratories upon return from the field. After sample collection and processing, the sampling equipment was cleaned according to the established protocols prior to use at the next well (Wilde, 2004).

\section{Analytical Methods}

Major ions, nutrients, trace elements, and organic compounds were analyzed by the USGS National Water Quality Laboratory in Denver, Colorado, by using published methods. Methods for major ions are published in Fishman and Friedman (1989) and Fishman (1993). Nutrients methods are published in Patton and Truitt (2000) and Patton and Kryskalla (2003). Trace-element methods are published in Fishman and Friedman (1989), Struzeski and others (1996), Garbarino (1999), and Garbarino and others (2006). Pesticide analysis was done by solid-phase extraction and gas chromatography/ mass spectrometry following the methods published in Zaugg and others (1995), Lindley and others (1996), Sandstrom and others (2001), and Madsen and others (2003). The ${ }^{87} \mathrm{Sr} / 86 \mathrm{Sr}$ isotopic ratios were analyzed at the USGS Isotope Laboratory in Menlo Park, California, in accordance with methods described by Kendall and McDonnell (1998). Analyses for $\delta \mathrm{D}$ and $\delta^{18} \mathrm{O}$ were done at the USGS Stable Isotope Laboratory in Reston, Virginia. Analytical methods for $\delta \mathrm{D}$ are described in Révész and Coplen (2008a), and analytical methods for $\delta^{18} \mathrm{O}$ are described in Révész and Coplen (2008b). ${ }^{3} \mathrm{H}$ was analyzed by internal gas proportional counting at the University of Miami Tritium Laboratory in Miami, Florida. Analytical methods for ${ }^{3} \mathrm{H}$ are documented in Östlund and Werner (1962) and Thatcher and others (1977). ${ }^{14} \mathrm{C}$ was analyzed at the National Ocean Sciences Accelerator Mass Spectrometry Facility at the Woods Hole Oceanographic Institution in Woods Hole, Massachusetts, by accelerator mass spectrometry. Methods for analyzing accelerator mass spectrometry results are described in Roberts and others (2010), and methods for determining and reporting ${ }^{14} \mathrm{C}$ ages are described in Karlen and others (1964), Olsson and Klasson (1970), Stuiver and Polach (1977), and Stuiver (1980). 


\section{Environmental Tracers}

Environmental tracers, such as ${ }^{87} \mathrm{Sr} / 86 \mathrm{Sr}, \delta \mathrm{D}, \delta 18 \mathrm{O},{ }^{3} \mathrm{H}$, and ${ }^{14} \mathrm{C}$ concentrations in groundwater, are useful for understanding where and when groundwater recharge occurred in an aquifer system. ${ }^{87} \mathrm{Sr} / 86 \mathrm{Sr}$ can be a useful tool for helping determine the source of dissolved constituents in groundwater, and $\delta \mathrm{D}$ and $\delta^{18} \mathrm{O}$ are useful indicators of conditions at the time and place of groundwater recharge. Lastly, ${ }^{3} \mathrm{H}$ and ${ }^{14} \mathrm{C}$ can provide information on the apparent age of the groundwater.

\section{Strontium Isotopic Ratios}

Strontium isotopic ratios, specifically the ratio of ${ }^{87} \mathrm{Sr} / 86 \mathrm{Sr}$, are useful in describing the source of groundwater and possible mixing of source waters (Kendall and McDonnell, 1998). When ${ }^{87} \mathrm{Sr} /{ }^{86} \mathrm{Sr}$ values increase or decrease from one location to the next along a flow path, mixing of geochemically different sources of water or mixing of water from different aquifer units could be occurring. Strontium can substitute for calcium, especially in carbonate rocks that are commonly found in subsurface geologic units in the Hueco Bolson (Hem, 1985; Banner, 2004; Musgrove and others, 2010; Bumgarner and others, 2012). As a result of this rock-water interaction, ${ }^{87} \mathrm{Sr} / 86 \mathrm{Sr}$ values can be used to evaluate sources of dissolved constituents in groundwater and to determine possible groundwater mixing (McNutt and others, 1990; Musgrove and Banner, 1993; Banner and others, 1994; Uliana and others, 2007; Musgrove and others, 2010). Water in specific geologic units is expected to have ${ }^{87} \mathrm{Sr} / 86 \mathrm{Sr}$ values that reflect the isotopic ratio of minerals in that specific aquifer unit; therefore, ${ }^{87} \mathrm{Sr} / 86 \mathrm{Sr}$ values can be used as a geochemical tracer of source waters originating from different geologic units (Kendall and McDonnell, 1998). By using ${ }^{87} \mathrm{Sr} / 86 \mathrm{Sr}$ values obtained from previous studies such as Teeple (2017), ${ }^{87} \mathrm{Sr} / 86 \mathrm{Sr}$ values measured in samples from Hueco Bolson wells can be compared to ${ }^{87} \mathrm{Sr} / 86 \mathrm{Sr}$ values in water collected from various areas within the Hueco Bolson region such as near the Franklin Mountains and the Rio Grande.

\section{Hydrogen and Oxygen Isotopic Ratios}

Ratios of the stable isotopes of the water molecule (hydrogen and oxygen) can yield isotopic signatures that are useful indicators of the regional recharge regimes of a hydrogeologic system (Faure, 1986). Plotting the ratio of hydrogen-2/hydrogen-1 (referred to as delta deuterium, or $\delta \mathrm{D}$, in per mil) to the ratio of oxygen-18/oxygen-16 isotopes (referred to as delta oxygen-18 or $\delta^{18} \mathrm{O}$, in per mil) can aid in analyzing when and from where the groundwater was initially recharged into the system (Faure, 1986; Uliana and others, 2007; Bumgarner and others, 2012). Craig (1961) used $\delta \mathrm{D}$ and $\delta^{18 O}$ isotopic analyses from multiple precipitation samples collected around the world to create a Global Meteoric Water Line (GMWL), a linear regression line calculated as $\delta \mathrm{D}=$
$8 \times \delta^{18} \mathrm{O}+10$. Changes along this line can be attributed to multiple factors including altitude, storm intensity, latitude, seasons, and continental climate (Fontes, 1980). Precipitation with larger amounts of the elevated $\delta \mathrm{D}$ and $\delta^{18} \mathrm{O}$ values (isotopically heavier) generally occurs in lower altitudes, lower latitudes, warmer weather, and closer to the coasts (Witcher and others, 2004). Values that deviate from the GMWL can be a result of two processes: (1) evaporation prior to recharge, and (2) oxygen isotope exchange with rocks (Witcher and others, 2004). Evaporation can cause preferential loss of water molecules containing the lighter stable isotopes of hydrogen and oxygen which can be seen with elevated $\delta \mathrm{D}$ and $\delta^{18} \mathrm{O}$ values. Water samples that indicate gains or losses of oxygen atoms from rock-water interaction tend to deviate from the GMWL in the lateral position because there is the gain or loss of only the oxygen element (Teeple, 2017).

\section{Tritium}

${ }^{3} \mathrm{H}$ is a radioactive isotope of hydrogen with a half-life of 12.32 years and usually has two sources: natural cosmogenic $3 \mathrm{H}$ and $3 \mathrm{H}$ produced by the atmospheric testing of nuclear weapons (Clark and Fritz, 1997; Lucas and Unterweger, 2000). The release of excess ${ }^{3} \mathrm{H}$ into the atmosphere occurred during widespread nuclear weapons testing from about 1950 to about 1970 (Motzer, 2008). Before nuclear weapons testing, the naturally occurring concentration of ${ }^{3} \mathrm{H}$ in the atmosphere ranged from about 2 to 8 tritium units (TU) (Motzer, 2008). From about 1950 to about 1970, widespread atomic bomb testing resulted in a substantial increase (more than $1.1 \times 10^{9} \mathrm{TU}$ ) of $3 \mathrm{H}$ in the atmosphere of the Northern Hemisphere (Motzer, 2008). Concentrations of ${ }^{3} \mathrm{H}$ in precipitation since 2006 have globally decreased to approximately pre-bomb background levels of 2 to $10 \mathrm{TU}$ (Clark and Fritz, 1997; Phillips and Castro, 2003). The elevated ${ }^{3} \mathrm{H}$ concentrations in the atmosphere beginning in about 1950 resulted in groundwater recharge containing appreciably higher ${ }^{3} \mathrm{H}$ concentrations compared to groundwater recharged before 1950. Consequently, ${ }^{3} \mathrm{H}$ is a good tracer for groundwater that was recharged after about 1950 . The use of $3 \mathrm{H}$ to analyze groundwater results in an apparent age in that definitive ages of groundwater cannot be determined, but rather, differences in ${ }^{3} \mathrm{H}$ concentrations can potentially distinguish if the groundwater was recharged before, during, or after widespread atomic bomb testing began in the 1950s. As noted by Hinkle (1996, p. 5), "the definition of modern water is a function of the dating tool used. Although different dating tools rely on different dates in defining the boundary between modern and old water, the range of these dates is small." The determination of groundwater age by using ${ }^{3} \mathrm{H}$ is relative to ${ }^{3} \mathrm{H}$ concentrations when samples were collected. ${ }^{3} \mathrm{H}$ is commonly measured in picocuries per liter $(\mathrm{pCi} / \mathrm{L})$ or in tritium units, where $3.22 \mathrm{pCi} / \mathrm{L}$ is equivalent to $1 \mathrm{TU}$ or 1 part ${ }^{3} \mathrm{H}$ in $10^{18}$ parts hydrogen (Lucas and Unterweger, 2000). 


\section{Carbon-14}

${ }^{14} \mathrm{C}$ is the radioactive isotope of carbon and is naturally produced in the upper atmosphere (Plummer and Busenberg, 2000). Kalin (2000) notes that the half-life used for calculating the radiocarbon age of most geologic and some hydrogeologic samples is the Libby half-life (Libby, 1955), which is 5,568 years. Because ${ }^{14} \mathrm{C}$ has a long radioactive half-life, it is useful for dating groundwater that is thousands to tens of thousands of years old (Kalin, 2000; Banner, 2004; Oden and Truini, 2013). Citing the work of Kalin (2000), Nishikawa and others (2004, p. 39) explained "carbon-14 data are expressed as percent modern carbon (pmc) by comparing ${ }^{14} \mathrm{C}$ activities to the specific activity of National Bureau of Standards [now the National Institute of Standards and Technology] oxalic acid: 13.56 disintegrations per minute per gram of carbon in the year 1950 equals 100 pmc (Kalin, 2000).”

Groundwater recharged after 1950 likely results in a ${ }^{14} \mathrm{C}$ activity value of 100 pmc or greater because atmospheric ${ }^{14} \mathrm{C}$ concentrations increased by as much as 20 percent from widespread atomic bomb testing in the 1950s and 1960s (Plummer and Busenberg, 2000). ${ }^{14} \mathrm{C}$ typically moves into groundwater through dissolved carbon dioxide $\left(\mathrm{CO}_{2}\right)$ in precipitation or in organic carbon dissolved in surface water and soil-pore water (Ingebritsen and Sanford, 1999; Raymond and Bauer, 2001). ${ }^{14} \mathrm{C}$ can enter surface water directly as water flows over the land towards stream channels (overland flow) or indirectly as the result of soil-pore water moving through the soil zone and discharging to a surface-water body (Linsley and others, 1982). Surface water in turn can provide a source of groundwater recharge through surface water-groundwater interactions. Along the groundwater's flow path, ${ }^{14} \mathrm{C}$ concentrations slowly begin to decrease as ${ }^{14} \mathrm{C}$ decays to nitrogen-14 $\left({ }^{14} \mathrm{~N}\right)$. Dilution of ${ }^{14} \mathrm{C}$ through geochemical processes, such as the dissolution of carbonates or $\mathrm{CO}_{2}$ from rocks and soil, can substantially alter the original ${ }^{14} \mathrm{C}$ concentration (Lemay, 2002). ${ }^{14} \mathrm{C}$ concentrations in groundwater may be altered, therefore, by the introduction of nonradioactive carbon-12 (12C) from exchange with carbon in rocks and soils that are millions of years old, resulting in apparent ${ }^{14} \mathrm{C}$ groundwater ages that are falsely old. Various types of geochemical modeling are used to correct for these effects to obtain better estimates of groundwater age (Plummer and others, 1994).

\section{Quality-Assurance and Quality-Control Procedures}

Quality-control data were collected during sampling to assess the variability and bias that may exist within the sample-collection procedures and laboratory analyses (USGS, variously dated). To test for this variability and bias, three field-blank samples, three sequential-replicate samples, and one matrix-spiked sample for organic compounds were collected in conjunction with environmental samples. All three field-blank samples were analyzed for inorganic constituents, and two of the field-blank samples were analyzed for organic compounds. In addition, two source-blank samples were collected in conjunction with two field-blank samples for inorganic constituent analysis.

\section{Field-Blank Analyses}

Field-blank samples were collected and processed at three well locations prior to the collection of environmental samples at those locations to ensure that equipment cleaning conducted in the field between the collection of samples from different wells was adequate and that the collection, processing, or transporting procedures in the field did not contaminate the environmental samples. In one field-blank sample, low concentrations of barium ( 0.15 microgram per liter $[\mu \mathrm{g} / \mathrm{L}])$, cobalt $(0.040 \mu \mathrm{g} / \mathrm{L})$, copper $(0.55 \mu \mathrm{g} / \mathrm{L})$, and thallium $(0.02 \mu \mathrm{g} / \mathrm{L})$ were detected. Aluminum $(3 \mu \mathrm{g} / \mathrm{L})$, cobalt $(0.104 \mu \mathrm{g} / \mathrm{L})$, copper $(0.51 \mu \mathrm{g} / \mathrm{L})$, manganese $(0.44 \mu \mathrm{g} / \mathrm{L})$, and nickel $(0.24 \mu \mathrm{g} / \mathrm{L})$ were detected in another field-blank sample. Concentrations of barium in the field-blank samples were small (approximately 0.2 percent of the barium concentrations measured in the environmental samples), but most of the other inorganic constituents detected in the field-blank samples were measured at similar concentrations in the environmental samples. The cause for low-level concentrations of some inorganic constituents in the field-blank samples is unknown. To avoid possible bias, values for constituents measured in environmental samples at concentrations that were less than or equal to those measured in field-blank samples were not included for interpretive purposes.

Calcium was also detected in all three field-blank samples, but concentrations in field-blank samples were considered negligible (less than $0.06 \mathrm{mg} / \mathrm{L}$ ) compared to concentrations in all the environmental samples (greater than $5 \mathrm{mg} / \mathrm{L}$ ). An aluminum concentration of $3 \mu \mathrm{g} / \mathrm{L}$ was detected in one source-blank sample, which would account for the aluminum concentration of $3 \mu \mathrm{g} / \mathrm{L}$ detected in the one field-blank sample. No organic compounds were detected in either of the fieldblank samples for organic analyses.

\section{Sequential-Replicate Analyses}

Three sequential-replicate samples were collected to measure the variability in results originating from sampling procedures and analytical methods. Inorganic constituents were measured in replicate samples that were collected by using a new, preconditioned 0.45-micron capsule filter. Capsule filters were replaced prior to collecting the sequential-replicate samples to prevent the possibility of filter loading, which might reduce the effective pore size of the filter (Horowitz and others, 1996). 
To evaluate the potential variability introduced during sample collection, processing, or laboratory analysis, the analytical results measured in an environmental sample were compared with those measured in the associated replicate sample by computing the relative percent difference (RPD) for each constituent. The RPD was computed by using the following equation:

$$
R P D=\frac{\left|C_{1}-C_{2}\right|}{\left(C_{1}+C_{2}\right) / 2} \times 100
$$

where

$C_{1} \quad$ is the concentration from the environmental sample, and

$C_{2} \quad$ is the concentration from the replicate sample. RPDs of 10 percent or less indicate good agreement between the paired results if the concentrations were sufficiently large compared to their associated laboratory reporting levels (LRLs) (Childress and others, 1999; Oden and others, 2011). An RPD was not computed if either of the paired results was reported as an estimated concentration or below the detection level. Most RPDs did not exceed 10 percent for constituents analyzed in the three sequential-replicate sample pairs collected during this study, indicating generally good agreement between the environmental and replicate sample concentrations. RPDs exceeded 10 percent (but were less than 20 percent) for seven trace elements (aluminum, antimony, cobalt, copper, iron, lithium, and uranium). Differences between the concentrations in paired samples where each sample concentration is low can result in large RPD values. RPDs for nutrients in one environmental-replicate pair were greater than 100 percent because nutrient concentrations in sample pairs were both very low (less than $0.4 \mathrm{mg} / \mathrm{L}$ ). In addition, RPDs were between 10 and 20 percent for two organic constituents (3,4-dichloroaniline and prometon) because concentrations were low (less than $0.02 \mu \mathrm{g} / \mathrm{L}$ ).

\section{Matrix-Spike Analysis}

A spiked environmental sample is an environmentalreplicate sample to which a known volume containing known concentrations of target constituents is added in the field (Wilde and others, 2004; Martin and others, 2009). Water was collected from the well and processed following standard procedures to produce two samples (USGS, variously dated; Shelton, 1994; Koterba and others, 1995). Spike solution is added to only one of the two water samples, resulting in spiked and unspiked samples (the matrix spike and the "background" sample, respectively). Matrix spikes are usually collected to help determine any matrix interference and the analyzing laboratory's ability to recover constituent concentrations (Zaugg and others, 1995; Menheer and Brigham, 1997; Mueller and others, 1997).

Unspiked and spiked environmental samples were used to assess bias and variability from possible degradation of pesticide constituents resulting in lower concentrations during sample processing, storage, and analysis (Mueller and others, 2015). Analytical recoveries of the spiked target constituents are expressed as percentages of expected (theoretical) concentrations. The percent recoveries of constituents in the spiked environmental sample was compared to laboratory recovery spiked samples to evaluate matrix interferences or degradation of organic compounds. Percent recovery is computed as follows:

$$
\begin{aligned}
& \text { Percent recovery }=[(\text { Cspiked }- \text { Cunspiked }) \\
& \times 100] / \text { Cexpected }
\end{aligned}
$$

where

Cspiked is the measured concentration in the spiked environmental sample, in micrograms per liter;

Cunspiked is the measured concentration in the unspiked environmental sample, in micrograms per liter; and

Cexpected is the theoretical concentration in the spiked environmental sample, in micrograms per liter, and is computed as follows:

$$
\text { Cexpected }=(\text { Csolution } \times \text { Vspike }) / \text { Vsample }
$$

where

Csolution is the concentration of constituent in the spike solution, in micrograms per liter;

Vspike is the volume of spike added to the environmental sample, in milliliters; and

Vsample is the volume of the environmental sample, in liters.

Constituent concentrations less than the LRL were set to zero for the purpose of calculating percent recovery.

A mixture of target constituents was added to one of the environmental-replicate samples for spike analysis. Percent recoveries were computed for each of the constituents, with the optimum value being 100 percent (Mueller and others, 2015; Shoda and others, 2017). Depending on the constituent, overall percent recoveries for this study ranged from approximately 54 to 96 percent, with each organic constituent detected in this study having a different range in percent recovery. For example, simazine, atrazine, prometon, and prometryn had percent recoveries in the range of 73 to 96 percent for spiked environmental samples, but deethylatrazine had a percent recovery from 60 to 70 percent, and 3,4-dichloroaniline had a percent recovery from 54 to 60 percent. If a selected constituent has a substantially high or low recovery, the environmental sample results of the pesticide constituents could be affected. Because recoveries for deethylatrazine and 3,4-dichloroaniline were consistently low in laboratory recovery spiked samples (less than 75 percent), all concentration results for those constituent detections are reported as estimated. Concentrations of selected organic compounds measured in the unspiked environmental samples that were less than their respective LRLs were considered irrelevant, and their recoveries were not evaluated in the matrix spike results. 


\section{Geochemical Assessment}

To better understand general water quality and possible sources and recharge areas for groundwater in the Hueco Bolson, water-quality samples were collected in 2016 and 2017 from 23 water-supply wells near El Paso, Tex. (fig. 2). Water-quality samples from 20 wells were analyzed for physical properties, major ions, nutrients, trace elements, and organic compounds in 2016. Additional analyses also included selected isotopes such as ${ }^{87} \mathrm{Sr} / 86 \mathrm{Sr}, \delta \mathrm{D},{ }^{18} \mathrm{O},{ }^{3} \mathrm{H}$, and ${ }^{14} \mathrm{C}$. Three additional groundwater wells were sampled in 2017 for the same constituent groups minus nutrients and organic compounds.

Physical properties and other constituents were used to evaluate general water quality and potential sources of groundwater in the Hueco Bolson system by examining and

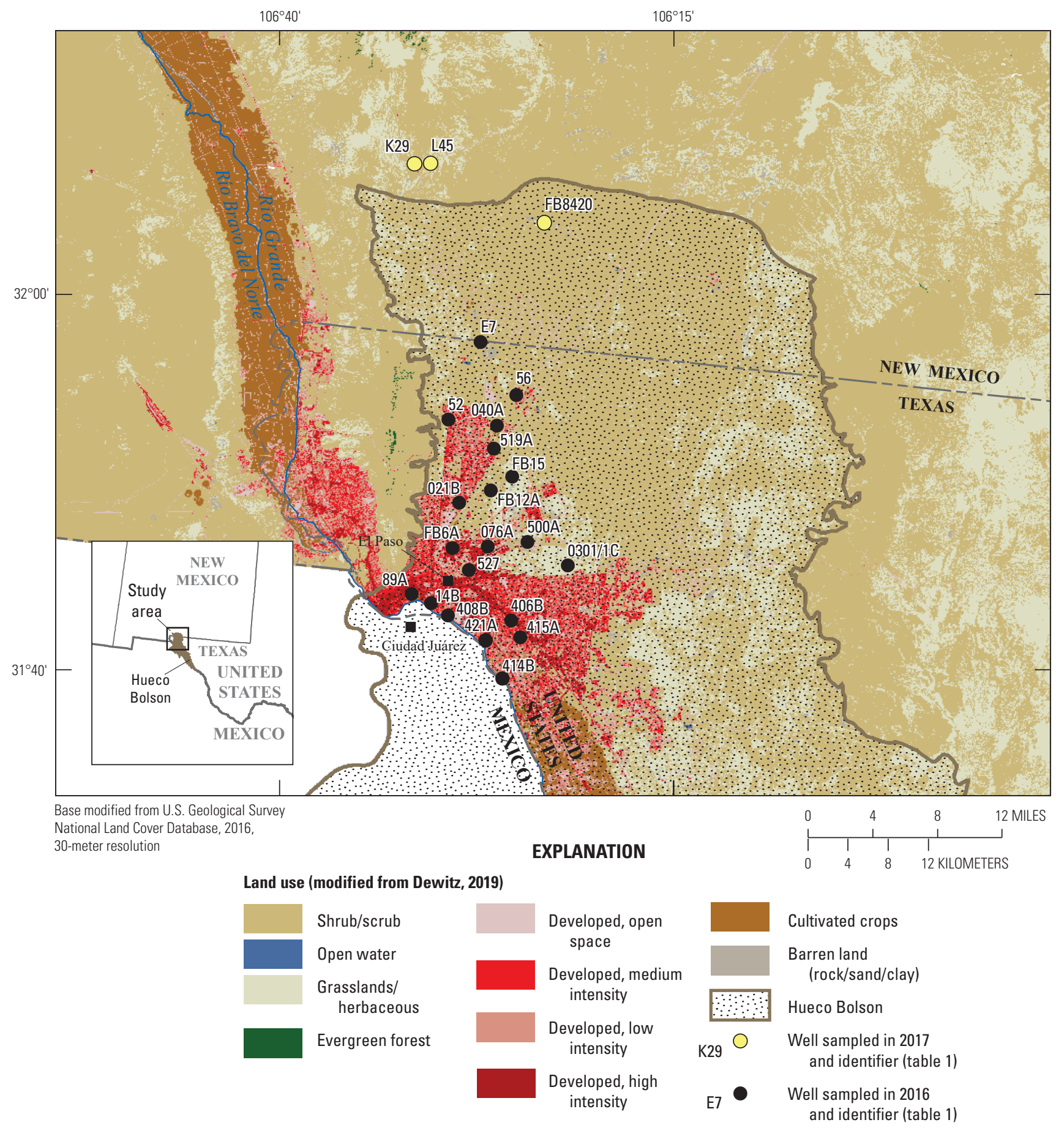

Figure 2. Land use in the Hueco Bolson study area in New Mexico and Texas, with locations of wells sampled in 2016 or 2017. 
comparing hydrochemical facies, dissolved solids, nutrients, trace elements, organic compounds, and environmental tracers such as ${ }^{87} \mathrm{Sr} /{ }^{86} \mathrm{Sr}, \delta \mathrm{D},{ }^{18} \mathrm{O},{ }^{3} \mathrm{H}$, and ${ }^{14} \mathrm{C}$ concentrations. These results were used in combination to identify the chemical characteristics of water in the Hueco Bolson and possible insights into potential recharge and sources areas for groundwater in the study area (Plummer and others, 2004). The qualitative geochemical analysis does not include a quantitative evaluation of residence times in the aquifer nor does it include geochemical flow-path modeling of the groundwater system.

\section{Hydrochemical Facies}

The composition of groundwater principally is controlled by the composition of recharge water, rock-water interaction, and the mixing of water from different sources. The term "hydrochemical facies" refers to a classification scheme used to describe water in terms of the major cation and anion milliequivalents composition. A trilinear diagram (Piper, 1944) is a useful tool for evaluating the relative abundance of major cations and anions and classifying hydrochemical facies or water types (fig. 3). Most of the water sampled from the Hueco Bolson wells were classified as sodium-chloride type water (within the yellow diamond in fig. 3). Higher magnesium and bicarbonate concentrations were measured in the water samples collected from four of the wells (K29, FB8420, 52, and FB6A) than other wells in the study area, resulting in water types different from those of typical sodium-chloride type waters. The sodium-chloride type water may be more a function of the region rather than land-use activities because the sodium-chloride type water is associated with wells representing different land-use types (Musgrove and Bexfield, 2017). The land use within the study area is predominantly urban near Ciudad Juárez, Mexico, and El Paso, Tex., with land-use types of shrub/scrub and cultivated crops mostly in areas along the Rio Grande (Dewitz, 2019; fig. 2).

\section{Dissolved Solids}

Dissolved-solids concentrations are a measure of how much dissolved constituents are in a sample. Sodium and chloride are often the primary constituents that contribute to elevated dissolved-solids concentrations (Hem, 1985). In this report, dissolved-solids concentrations of less than or equal to $1,000 \mathrm{mg} / \mathrm{L}$ were considered indicative of freshwater, whereas dissolved-solids concentrations greater than $1,000 \mathrm{mg} / \mathrm{L}$ and less than 10,000 mg/L were considered indicative of brackish water. Dissolved-solids concentrations greater than 1,000 mg/L were measured in samples collected only from four wells in the study area (Ging and others, 2019). Three of the four wells from which samples with the highest dissolved-solids concentrations were measured (wells 414B, 415A, and 421A; fig. 4B) were near the Rio Grande (figs. 2 and 5). In a similar study where water-quality samples were collected in 1997, the highest dissolved-solids concentrations were also measured in the samples collected from wells near the Rio Grande (Anderholm and Heywood, 2003). In the current study, dissolved-solids concentrations ranging from 501 to $1,000 \mathrm{mg} / \mathrm{L}$ were measured in samples collected from most of the wells in the study area (fig. $4 A$ and 5). The U.S. Environmental Protection Agency (EPA) secondary drinkingwater standard for dissolved solids is $500 \mathrm{mg} / \mathrm{L}$ for color, taste, and odor issues (EPA, 2009); dissolved-solids concentrations of $500 \mathrm{mg} / \mathrm{L}$ or less were measured in the samples collected from nine wells (Ging and others, 2019). Dissolved-solids concentrations in groundwater can increase with increasing well depth because more minerals dissolve into the water as it progresses farther below land surface (Hem, 1985), but the opposite pattern was observed in the water-quality samples collected during this study. This unusual pattern of decreasing dissolved-solids concentrations with increasing well depth is probably a function of the spatial distribution of the wells, where the shallower wells with the higher dissolved-solids concentrations are the wells closest to the Rio Grande (fig. $4 B$ and 5; table 1).

Relatively high sodium concentrations have been documented in surface-water samples collected from the Rio Grande near El Paso, Tex. (Lurry and others, 1998) and may be contributing to the relatively high sodium concentrations measured in groundwater samples collected from wells near the river. A large coefficient of determination $\left(\mathrm{R}^{2}\right)$ value (Helsel and Hirsch, 2002) of 0.7742 for a regression line fitted to the sodium and dissolved-solids concentrations indicates that sodium concentrations increase with increasing dissolvedsolids concentrations (fig. $6 \mathrm{~A}$ ); this relation is consistent with sodium being a large component of the dissolved-solids concentration. The hydrochemical facies diagram also indicates that samples from most of the wells contain sodium-chloride type water (fig. 3). Samples from two wells (wells FB6A and FB8420) were outliers on the sodium and dissolved-solids graph, and those two wells were outside the sodium-chloride type water on the trilinear diagram (figs. 3 and $6 A$ ). The molar ratio of sodium and chloride in groundwater from wells in this study is variable compared to the one-to-one ratio line, which is indicative of a natural salt source such as halite. Higher sodium than chloride molar concentrations were measured in the samples collected from about 70 percent of the wells, consistent with sodium being the major component of the dissolved-solids concentration in most of the wells that were sampled (fig. 6B). Anderholm and Heywood (2003) reported similar results from analyses of samples from wells in an area similar to the Hueco Bolson in 2017; sodium concentrations generally increased linearly with increasing chloride concentrations, thus indicating that dilute recharge water is likely mixing with sodium-chloride brine water as the groundwater migrates away from the recharge area. 


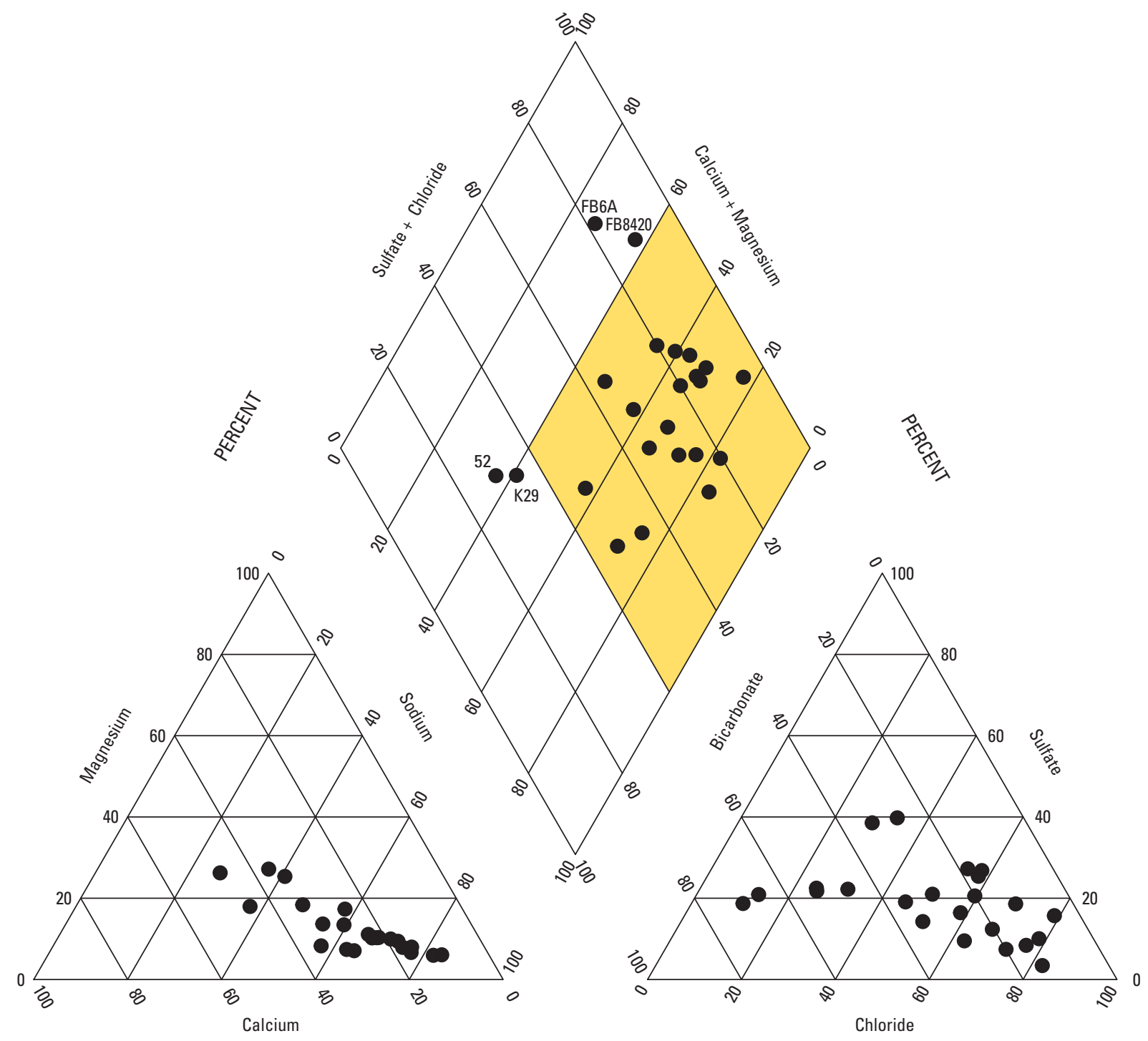

PERCENT

EXPLANATION

Sodium-chloride type waters

Well and identifier (table 1)

Figure 3. The relative abundance of major cations and anions in groundwater samples collected in New Mexico and Texas in the Hueco Bolson study area and identification of sodium-chloride type waters, 2016-17.

\section{Nutrients}

Nitrogen and phosphorus are the most common nutrients in groundwater. Elevated nitrogen and phosphorus concentrations in groundwater frequently result from surface-water infiltration in agricultural or municipal areas where nutrient sources typically include livestock manure, septic systems, wastewater treatment systems, and fertilizers (Dubrovsky and others, 2010). National background concentrations of nitrate, the most common form of nitrogen in groundwater, are estimated to be $1 \mathrm{mg} / \mathrm{L}$ (Dubrovsky and others, 2010). Samples collected for this study were analyzed for nitrogen as nitrate plus nitrite and nitrite. Nitrite concentrations in the study area were low, with detectable concentrations less than $0.1 \mathrm{mg} / \mathrm{L}$ (Ging and others, 2019). Because nitrite concentrations were low, concentrations for nitrate plus nitrite analyses were considered equivalent to nitrate concentrations and are referred to in this report simply as nitrate concentrations. 
Table 1. Wells sampled in New Mexico and Texas in the Hueco Bolson study area, 2016-17.

[USGS, U.S. Geological Survey; n/a, not available]

\begin{tabular}{|c|c|c|c|c|}
\hline Well identifier & USGS station number (USGS, 2019) & State & Date sampled & $\begin{array}{l}\text { Well depth, in feet below } \\
\text { land surface }\end{array}$ \\
\hline E7 & 320003106250401 & Texas & 08-29-2016 & 875 \\
\hline 56 & 315724106222501 & Texas & 08-29-2016 & 670 \\
\hline 52 & 315543106263501 & Texas & 08-30-2016 & 1,152 \\
\hline $040 \mathrm{~A}$ & 315541106232901 & Texas & 08-30-2016 & 870 \\
\hline $519 \mathrm{~A}$ & 315425106233101 & Texas & $08-31-2016$ & 1,140 \\
\hline $500 \mathrm{~A}$ & 314939106204401 & Texas & $08-31-2016$ & 720 \\
\hline 021B & 315120106252001 & Texas & 09-01-2016 & 1,155 \\
\hline $406 \mathrm{~B}$ & 314522106211301 & Texas & 09-01-2016 & 620 \\
\hline 076A & 314910106231101 & Texas & 09-02-2016 & 940 \\
\hline 527 & 314749106241401 & Texas & 09-02-2016 & $\mathrm{n} / \mathrm{a}$ \\
\hline 414B & 314214106212101 & Texas & 09-19-2016 & 425 \\
\hline $421 \mathrm{~A}$ & 314409106224001 & Texas & 09-19-2016 & 564 \\
\hline 0301/1C & 314836106180301 & Texas & $09-20-2016$ & 480 \\
\hline FB6A & 314853106252301 & Texas & $09-20-2016$ & 806 \\
\hline FB12A & 315211106232202 & Texas & $09-21-2016$ & 1,140 \\
\hline FB15 & 315305106222001 & Texas & $09-21-2016$ & 819 \\
\hline 408B & 314516106251601 & Texas & $09-22-2016$ & $\mathrm{n} / \mathrm{a}$ \\
\hline $415 \mathrm{~A}$ & 314432106203101 & Texas & $09-22-2016$ & 465 \\
\hline $14 \mathrm{~B}$ & 314612106273901 & Texas & $09-23-2016$ & 950 \\
\hline $89 \mathrm{~A}$ & 314548106262401 & Texas & 09-23-2016 & 866 \\
\hline K29 & 320906106302901 & New Mexico & $05-31-2017$ & 800 \\
\hline L45 & 320914106292701 & New Mexico & $05-31-2017$ & 1,100 \\
\hline FB8420 & 320645106215101 & New Mexico & 06-01-2017 & $\mathrm{n} / \mathrm{a}$ \\
\hline
\end{tabular}

Nitrate concentrations in the groundwater samples collected in the study area ranged from less than the long-term method detection level of $0.04 \mathrm{mg} / \mathrm{L}$ to $6.2 \mathrm{mg} / \mathrm{L}$ (Ging and others, 2019). No samples collected from the Hueco Bolson wells had nitrate concentrations greater than $10 \mathrm{mg} / \mathrm{L}$, which is the national drinking-water standard for nitrate (fig. $7 \mathrm{~A}$; EPA, 2009). Three samples from three wells (wells 52, 040A, and FB6A) were the only samples that had nitrate concentrations greater than $2 \mathrm{mg} / \mathrm{L}$ (figs. 2 and $7 B$ ). In about 50 percent of the samples collected, nitrate concentrations were between 1 and $2 \mathrm{mg} / \mathrm{L}$, and the highest nitrate concentration ( 6.2 $\mathrm{mg} / \mathrm{L}$ ) was measured in the sample collected from well FB6A (fig. 7B). Nitrate concentrations tend to increase with increasing dissolved-oxygen concentrations indicating that most of the elevated nitrate concentrations (greater than $1 \mathrm{mg} / \mathrm{L}$ ) are associated with dissolved-oxygen concentrations greater than $1 \mathrm{mg} / \mathrm{L}$ (fig. $7 B$ ). Potential sources of nitrate could be related to urban development in Ciudad Juárez, Mexico, and El Paso, Tex., or cultivated-crop land along the Rio Grande (fig. 2). Orthophosphate was the only phosphorus constituent analyzed in samples collected for this study. All orthophosphate concentrations were less than $0.1 \mathrm{mg} / \mathrm{L}$ in the groundwater samples; therefore, most of the nutrients detected in the study were primarily composed of nitrogen, particularly nitrate (Ging and others, 2019).

\section{Trace Elements}

Trace elements are present in small amounts in the environment and can be from natural and manmade sources (Ayotte and others, 2011). Concentrations of trace elements are more likely to be higher in groundwater than in surface water because of the movement of water through the rocks underground that make up the aquifers. Groundwater that has been in an aquifer for a long time has had more time to interact with the rocks and aquifer materials, thereby causing potential increases in trace element concentrations. Human activities also can affect concentrations of trace elements in groundwater (Ayotte and others, 2011).

The most commonly detected trace elements in samples from the Hueco Bolson wells with concentrations greater than $1 \mu \mathrm{g} / \mathrm{L}$ were arsenic, barium, boron, chromium, copper, 

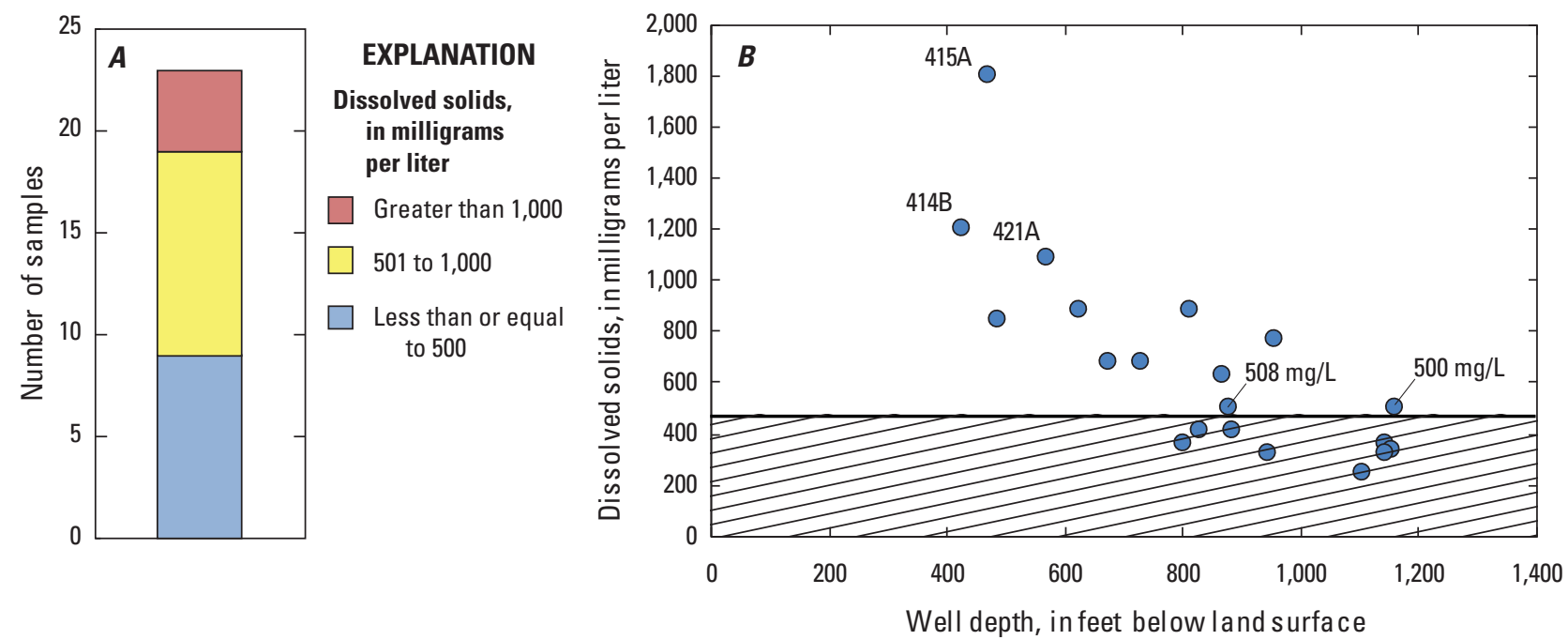

\section{EXPLANATION}
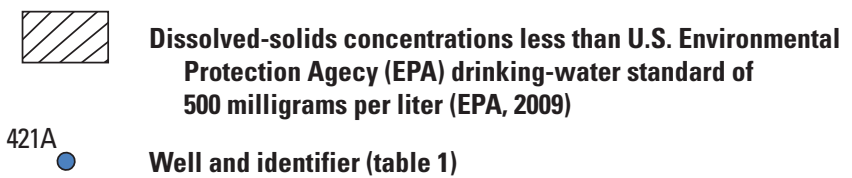

Figure 4. Dissolved-solids concentrations measured in samples collected from wells in New Mexico and Texas in the Hueco Bolson study area during 2016-17: $A$, numbers of samples containing specified ranges of dissolved-solids concentrations, and $B$, relation between dissolved-solids concentration and well depth.

iron, lithium, manganese, molybdenum, selenium, uranium, vanadium, and zinc (Ging and others, 2019). Some of the higher iron and manganese concentrations (greater than 10 $\mu \mathrm{g} / \mathrm{L}$ ) were associated with wells with lower dissolved-oxygen concentrations (less than or equal to $0.2 \mathrm{mg} / \mathrm{L}$ ), indicating that the iron and manganese concentrations could be affected by oxidation and reduction conditions (Ayotte and others, 2011; Ging and others, 2019). Similar findings were discussed in a previous study by Anderholm and Heywood (2003).

Of all trace elements measured in the groundwater samples obtained in this study, only arsenic concentrations exceeded the EPA-designated drinking-water standard of 10 $\mu \mathrm{g} / \mathrm{L}$ (EPA, 2009) in samples from 4 of 23 wells (17 percent); these 4 wells were located near the Rio Grande (table 2; fig. 8). Three of the wells where samples with the highest uranium concentrations (greater than $10 \mu \mathrm{g} / \mathrm{L}$ ) measured were also near the Rio Grande, and two of those wells were the same wells from which samples with high arsenic concentrations were obtained (figs. 8 and 9). The most common anthropogenic sources of arsenic include arsenic-based pesticides, coal combustion, and ore smelting (Hem, 1985). Uranium is a naturally occurring metal in the environment and can be mined in areas with large deposits. Anthropogenic sources of uranium concentrations include abandoned uranium mines, dissolution of mine tailings, emissions from nuclear industries, and combustion of coal (Szabo and others, 2012). Arsenic and uranium can naturally occur in certain types of sediments and bedrock, such as rocks of volcanic origin (Scanlon and others, 2005). The Hueco Bolson is part of the Rio Grande aquifer system, and concentrations of arsenic and uranium exceeding $5 \mu \mathrm{g} / \mathrm{L}$ have been measured in groundwater of the Rio Grande aquifer system (Musgrove and Bexfield, 2017). Because other trace elements such as molybdenum and boron that are associated with volcanic rocks were detected in the study area, the primary sources of the arsenic and uranium detected in the samples collected for this study may be geologic (volcanic) rather than anthropogenic in origin (Scanlon and others, 2005). Arsenic and uranium are more soluble in oxygen-rich environments such as surface water, and the higher dissolved-oxygen concentrations in the Rio Grande allow arsenic and uranium to be transported within the river (Robertson, 1991; Levings and others, 1998). In addition, arsenic and uranium are frequently detected in surface-water samples collected from the Rio Grande upstream from Ciudad Juárez, Mexico, and El Paso, Tex., which could indicate that these trace elements are being transported downstream from areas with volcanic rock (Levings and other, 1998). According to Heywood and Yager (2003), the Rio Grande is hydraulically connected to the Hueco Bolson, and water from the river can seep through the alluvium into shallow parts of the aquifer system in the Rio Grande valley, thus possibly accounting for the arsenic and uranium detections in the groundwater. 


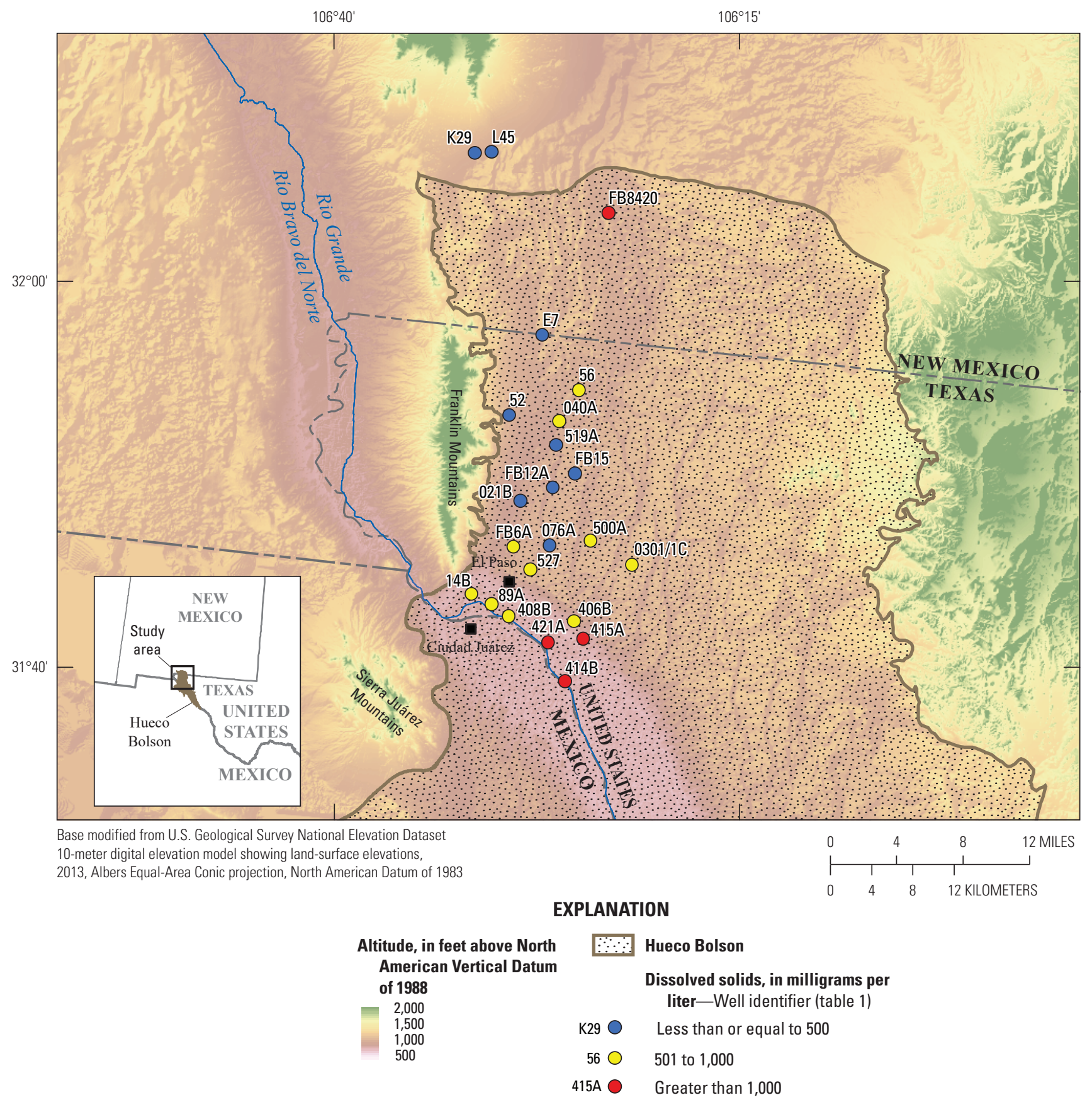

Figure 5. Concentrations of dissolved solids measured in groundwater samples collected from wells in New Mexico and Texas in the Hueco Bolson study area, 2016-17. 

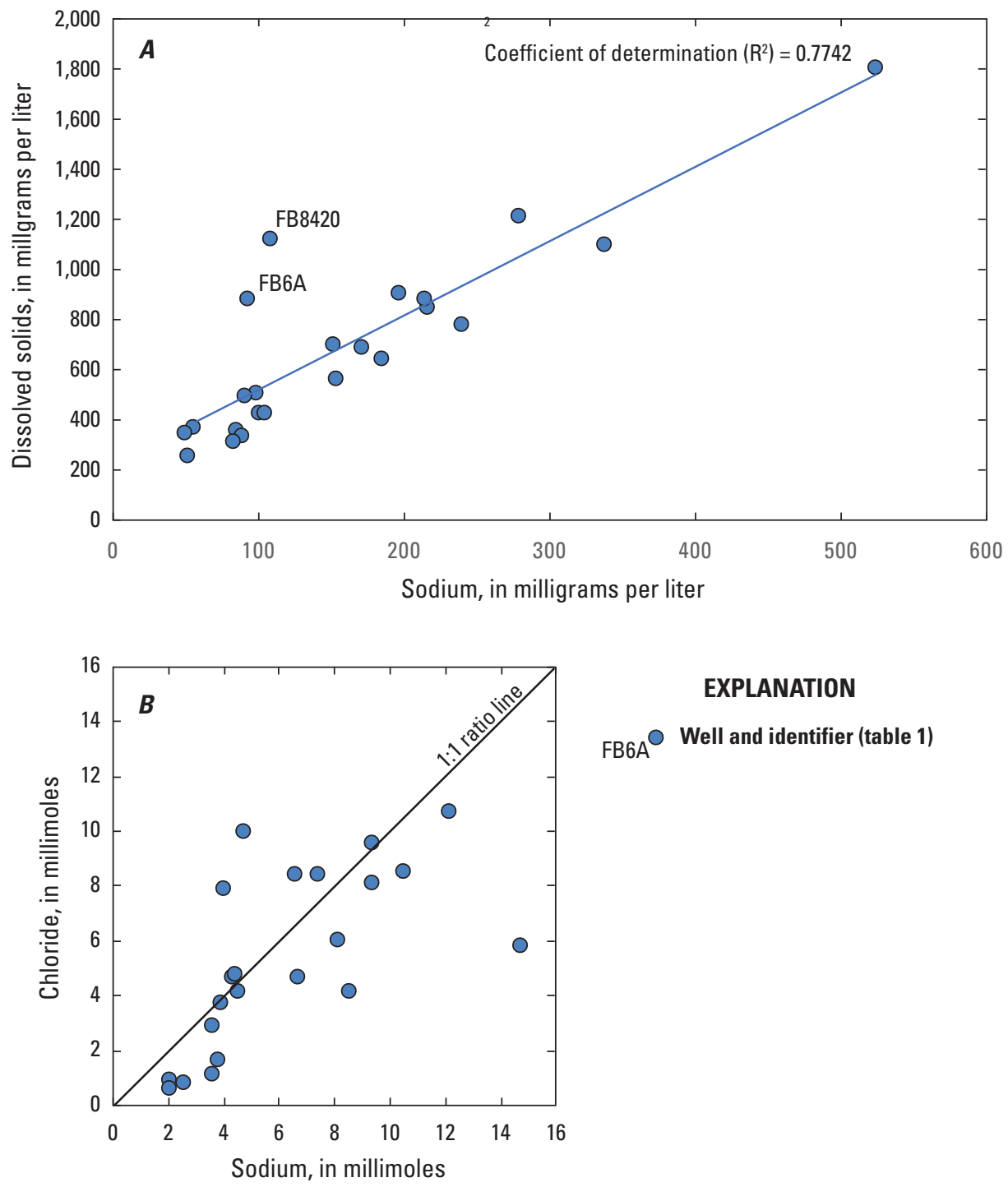

EXPLANATION

$\mathrm{FB}_{6 \mathrm{~A}} \bigcirc$ Well and identifier (table 1)

Figure 6. Concentrations of $A$, dissolved solids and sodium and $B$, chloride and sodium measured in groundwater samples collected from wells in New Mexico and Texas in the Hueco Bolson study area, 2016-17.

\section{Organic Compounds}

Detections of organic compounds such as pesticides in groundwater samples are potential indicators of anthropogenic effects on water quality. Organic compounds detected in groundwater samples likely result from surface water containing pesticides seeping into the groundwater in the study area. Groundwater samples were analyzed for 83 organic compounds. Of the 23 wells that were sampled, organic compounds were detected in samples from 5 wells. Three of the five groundwater samples with detected amounts of organic compounds were obtained from wells near the Rio Grande (fig. 10). The organic compounds that were detected in samples in this study were simazine, prometryn, prometon, atrazine, deethylatrazine, and 3,4-dichloroaniline (Ging and others, 2019). All the organic compounds detected are herbicides except for deethylatrazine and 3,4-dichloroaniline, which are degradates of herbicide compounds. Herbicide use may be associated with urban development in Ciudad Juárez, Mexico, and El Paso, Tex., or cultivated-crop land along the Rio Grande (fig. 2). All concentrations for these organic compounds were low (less than $0.03 \mu \mathrm{g} / \mathrm{L}$ ). Multiple organic compounds are often detected in the samples collected from a single well; two or three organic compounds were measured in each of the samples collected from four of the five wells (wells 408B, 421A, FB6A, and 040A) with detected amounts of any organic compounds (Ging and others, 2019; fig. 10). 


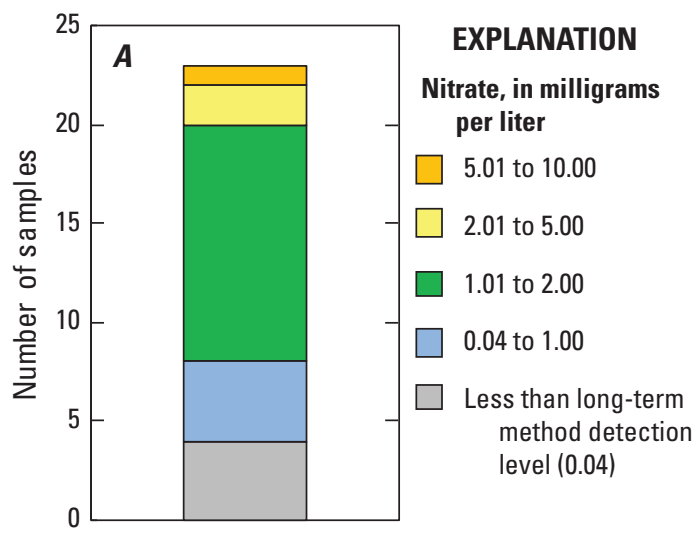

Note: The Maximum Contaminant Level (MCL) drinkingwater standard for nitrate is $10 \mathrm{mg} / \mathrm{L}$ (U.S. Environmental Protection Agency, 2009).

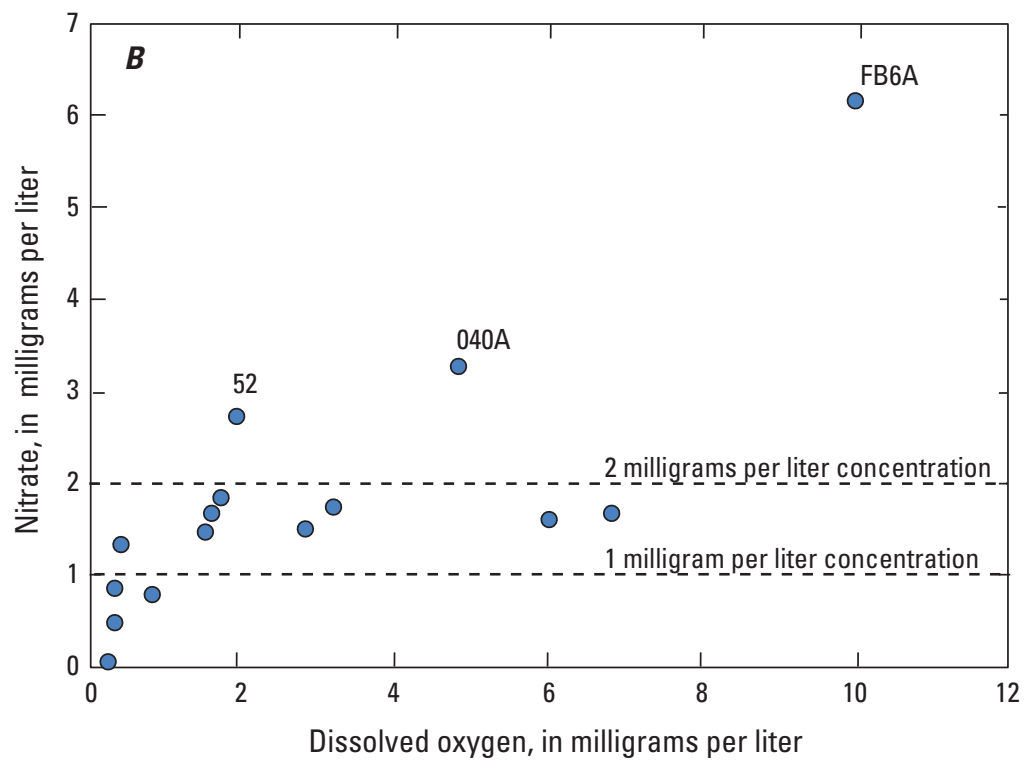

EXPLANATION

FB6A $\bigcirc$ Well and identifier (table 1)

Figure 7. Nitrate concentrations measured in samples collected from wells in New Mexico and Texas in the Hueco Bolson study area during 2016-17: $A$, numbers of samples containing specified ranges of nitrate concentrations, and $B$, relation between nitrate concentration and dissolved-oxygen concentration.

Table 2. Trace elements detected in groundwater samples collected from wells in New Mexico and Texas in the Hueco Bolson study area, with U.S. Environmental Protection Agency designated drinking-water standards for trace elements, and percentage of wells where the collected samples exceeded the standard for selected trace elements, 2016-17.

$[\mu \mathrm{g} / \mathrm{L}$, micrograms per liter]

\begin{tabular}{lccc}
\hline Trace element & $\begin{array}{c}\text { Drinking-water standard, } \\
\text { in } \mathbf{\mu g} / \mathbf{L}\end{array}$ & $\begin{array}{c}\text { Percentage of wells } \\
\text { with detections }\end{array}$ & $\begin{array}{c}\text { Detected concentrations that exceeded } \\
\text { the applicable drinking-water standard, } \\
\text { in percent }\end{array}$ \\
\hline Antimony & 6 & 87 & 0 \\
Arsenic & 10 & 100 & 17 \\
Barium & 2,000 & 100 & 0 \\
Boron & 6,000 & 100 & 0 \\
Chromium & 100 & 70 & 0 \\
Lead & 15 & 96 & 0 \\
Manganese & 300 & 70 & 0 \\
Molybdenum & 40 & 100 & 0 \\
Selenium & 50 & 91 & 0 \\
Uranium & 30 & 100 & 0 \\
\hline
\end{tabular}

1U.S. Environmental Protection Agency, 2009. 


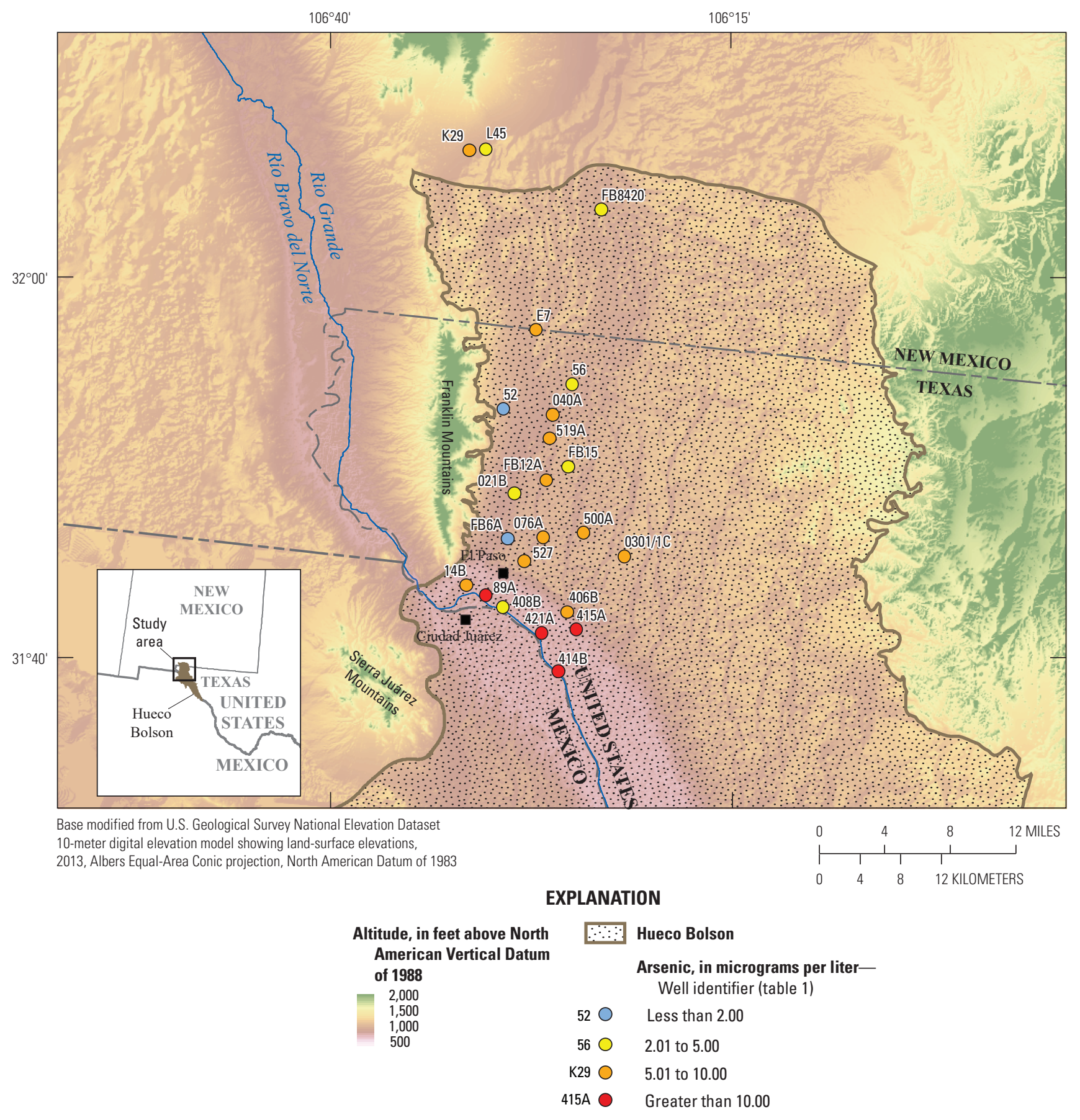

Figure 8. Concentrations of arsenic measured in groundwater samples collected from wells in New Mexico and Texas in the Hueco Bolson study area, 2016-17. 


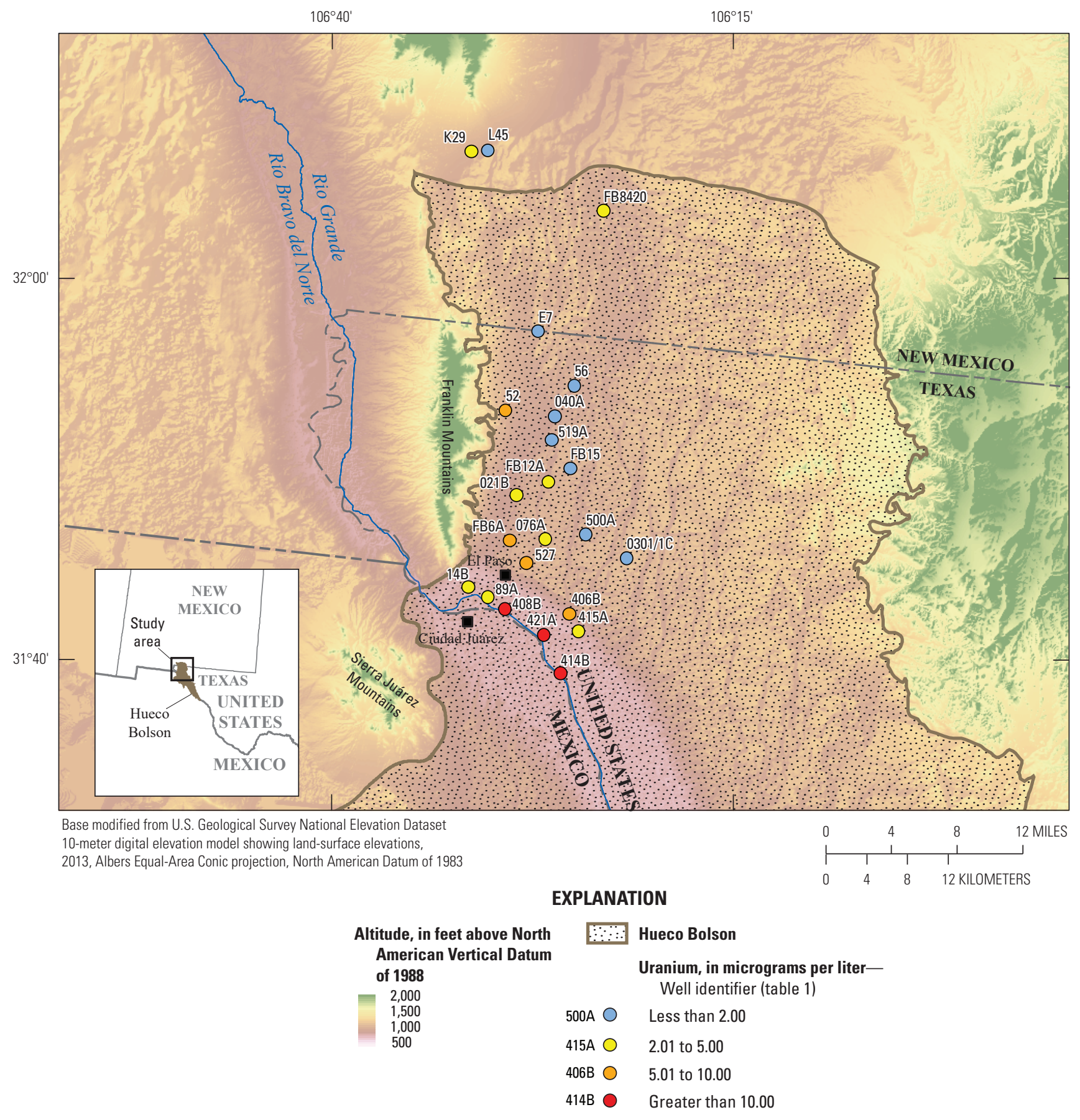

Figure 9. Concentrations of uranium measured in groundwater samples collected from wells in New Mexico and Texas in the Hueco Bolson study area, 2016-17. 


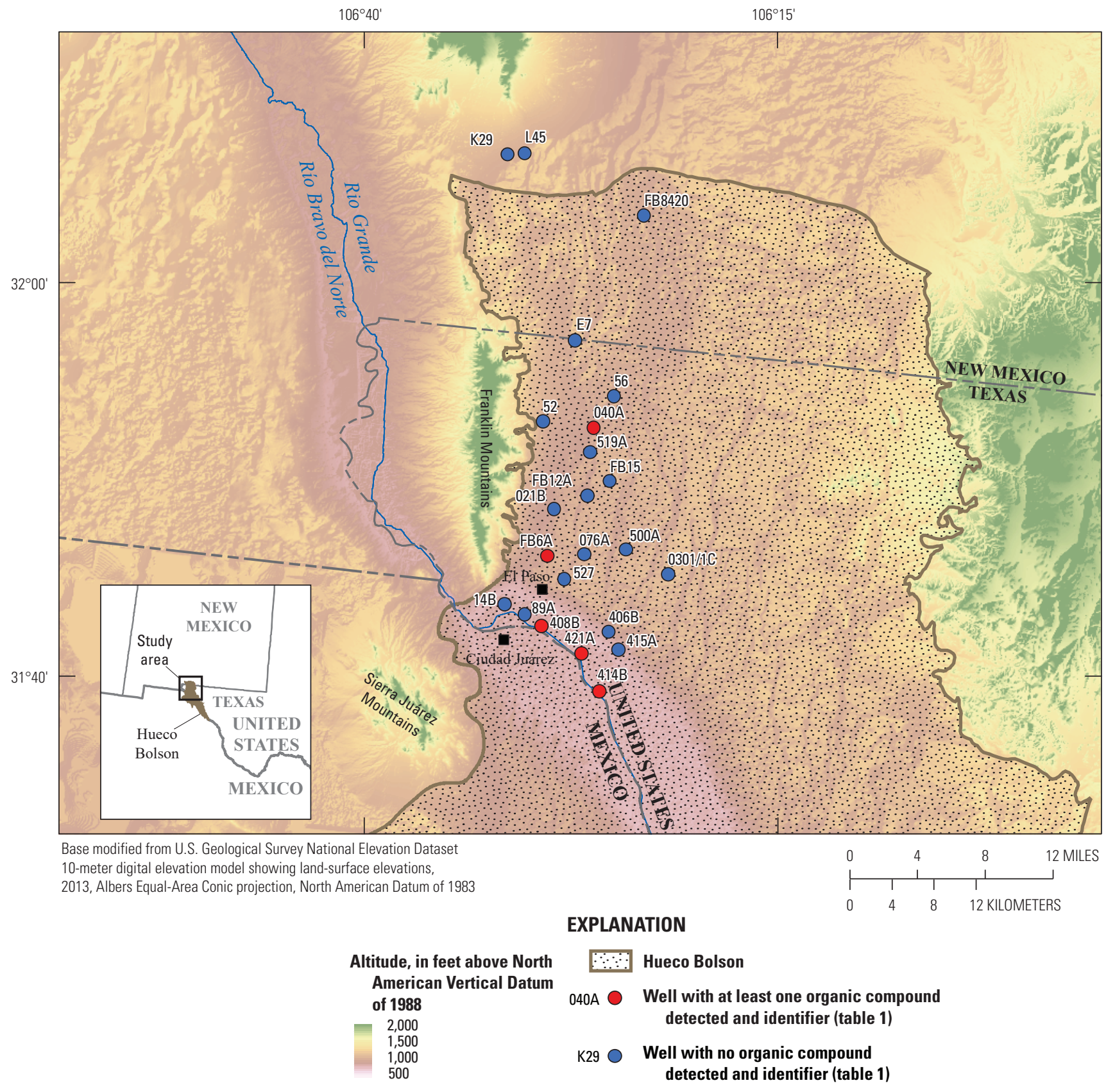

Figure 10. Wells with detections of organic compounds in groundwater samples in New Mexico and Texas in the Hueco Bolson study area, 2016-17. 


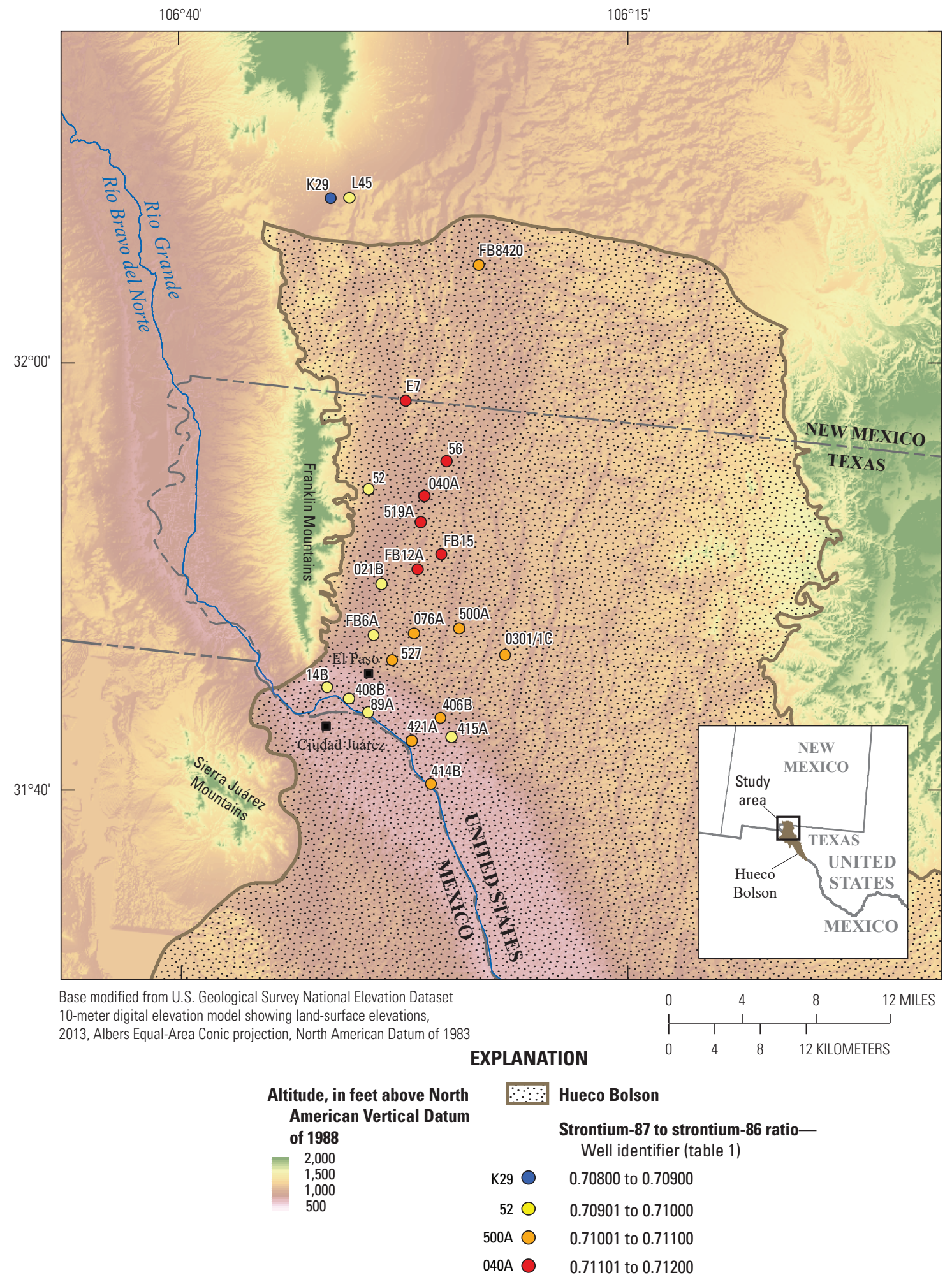

Figure 11. Strontium-87 to strontium-86 ratios in groundwater samples collected from wells in New Mexico and Texas in the Hueco Bolson study area, 2016-17. 


\section{Environmental Tracers}

Environmental tracers, such as ${ }^{87} \mathrm{Sr} / 86 \mathrm{Sr}, \delta \mathrm{D}, \delta 18 \mathrm{O},{ }^{3} \mathrm{H}$, and ${ }^{14} \mathrm{C}$ concentrations in groundwater, are useful for understanding where and when groundwater recharge occurred in the aquifer system. The isotopic ratio of ${ }^{87} \mathrm{Sr} / 86 \mathrm{Sr}$ can provide a useful tool for helping determine the source of dissolved constituents in water because the ${ }^{87} \mathrm{Sr} / 86 \mathrm{Sr}$ ratio undergoes negligible fractionation during mineral-solution reactions (Banner, 2004; Bumgarner and others, 2012). Therefore, ${ }^{87} \mathrm{Sr} /{ }^{86} \mathrm{Sr}$ values in water are expected to reflect the isotopic ratio of minerals in the aquifer system from rock-water interaction because fractionation is limited. The ${ }^{87} \mathrm{Sr} / 86 \mathrm{Sr}$ values in samples from five wells near the Rio Grande ranged from 0.70950 to 0.71011 (fig. 11), which is similar to the mean ${ }^{87} \mathrm{Sr} / 86 \mathrm{Sr}$ value $(0.71019)$ that Teeple $(2017$, p. 67) reported for groundwater samples collected from the Rio Grande alluvium (Ging and others, 2019). In addition, ${ }^{87} \mathrm{Sr} / 86 \mathrm{Sr}$ values (ranging from 0.71102 to 0.71164 ) were slightly higher in groundwater samples from six wells collected in the central and northern part of study area, east of the Franklin Mountains, compared to ${ }^{87} \mathrm{Sr} / 86 \mathrm{Sr}$ values measured in groundwater samples collected from wells near the Rio Grande (Ging and others, 2019; fig. 11). Teeple (2017) reported similar ${ }^{87} \mathrm{Sr} / 86 \mathrm{Sr}$ values in samples from the Mesilla Basin near the Franklin Mountains, and citing the work of others, stated that the samples may represent groundwater originating from the uplift areas surrounding the Mesilla Basin, which were formed from Tertiary volcanic activity (Witcher and others, 2004). The lower ${ }^{87} \mathrm{Sr} / 86 \mathrm{Sr}$ values $(0.70996$ and 0.70925$)$ measured in the samples collected from two wells near the Franklin Mountains (wells 52 and 021B, respectively) may indicate recharge water from a different, deeper geologic area compared to the groundwater obtained from other, shallower wells east of the Franklin Mountains (Ging and others, 2019; fig. 11). Wells 52 and $021 \mathrm{~B}$ are more than 1,150 feet deep (about 351 meters), whereas other wells east of the Franklin Mountains range from 670 to 1,140 feet deep (about 204 to 347 meters) (Ging and others, 2019; fig. 11; table 1). From the ${ }^{87} \mathrm{Sr} / 86 \mathrm{Sr}$ values in this study, it appears that groundwater from the central and northern parts of the study area may predominantly receive recharge water from precipitation that falls in the Franklin Mountains area, whereas groundwater in the southern part of the study area may predominantly receive recharge water from the Rio Grande valley.

Groundwater samples in the study area also were analyzed for $\delta \mathrm{D}$ and $\delta^{18} \mathrm{O}$ to help with the determination of source and recharge areas. The ratios of $\delta \mathrm{D}$ to $\delta 18 \mathrm{O}$ are useful indicators of conditions present at the time and place of groundwater recharge (Faure, 1986; Uliana and others, 2007).
A comparison of $\delta \mathrm{D}$ and $\delta^{18} \mathrm{O}$ in groundwater samples can be used to evaluate the evaporation process along a flow path because evaporation causes the preferential loss of water molecules containing the lighter stable isotopes of hydrogen (hydrogen-1) and oxygen (oxygen-16) and therefore deviation from the GWML (Witcher and others, 2004). The relation of $\delta \mathrm{D}$ and $\delta^{18} \mathrm{O}$ values measured in groundwater samples to the GMWL can help determine changes to groundwater chemistry caused by precipitation seeping into the aquifer. Evaporation, mixing with nonmeteoric water, or hydrothermal alteration of deeper, older waters can account for $\delta \mathrm{D}$ and $\delta^{18} \mathrm{O}$ values that deviate from the GMWL (Witcher and others, 2004). Most of the $\delta \mathrm{D}$ to $\delta^{18} \mathrm{O}$ ratios for the groundwater samples collected during this study plot near the GMWL (fig. 12A). The $\delta \mathrm{D}$ to $\delta^{18} \mathrm{O}$ ratios for five samples collected from wells near the Rio Grande plotted below the GMWL and were similar to $\delta \mathrm{D}$ to $\delta^{18} \mathrm{O}$ ratios reported in previous studies describing groundwater samples collected from wells near the Rio Grande (Anderholm and Heywood, 2003; Phillips and others, 2003; Eastoe and others, 2008 ; fig. $12 B$ ). The pattern of $\delta \mathrm{D}$ to $\delta^{18} \mathrm{O}$ ratios plotting below the GMWL indicates that the source of recharge for the wells along the Rio Grande is likely different from the source of recharge for the rest of the wells in the study area. This finding is consistent with the recharge information interpreted from differences in ${ }^{87} \mathrm{Sr} / 86 \mathrm{Sr}$ values. As in previous studies such as Anderholm and Heywood (2003) and Phillips and others (2003), the isotopic composition of groundwater samples obtained from the five wells near the Rio Grande is similar to the isotopic composition of surface water from the Rio Grande. The $\delta \mathrm{D}$ and $\delta^{18} \mathrm{O}$ values measured in samples collected from the wells near the Rio Grande during this study follow the Rio Grande evaporation line published in Phillips and others (2003) (fig. 12A).

Groundwater samples in the study area were analyzed for ${ }^{3} \mathrm{H}$ and ${ }^{14} \mathrm{C}$ to gain additional insights regarding the age of the groundwater. Given the short half-life of ${ }^{3} \mathrm{H}$, the presence of ${ }^{3} \mathrm{H}$ in groundwater is indicative of groundwater recharge within about the past 70 years. Interpreting groundwater ages with ${ }^{3} \mathrm{H}$ is qualitative in that it can provide insight into distinguishing water recharged before and after nuclear weapons testing. Because ${ }^{14} \mathrm{C}$ has a longer radioactive half-life compared to ${ }^{3} \mathrm{H}$, it is useful for determining the age of groundwater that is thousands to tens of thousands of years old (Oden and Truini, 2013). The age of groundwater is commonly qualified as an "apparent age" because chemical processes affect the environmental tracers used to determine age. Musgrove and others (2010, p. 42) explain that "because it is not possible to identify and account for all physical and chemical processes that might affect groundwater age-tracer results, the apparent age of groundwater is most appropriately reported." 

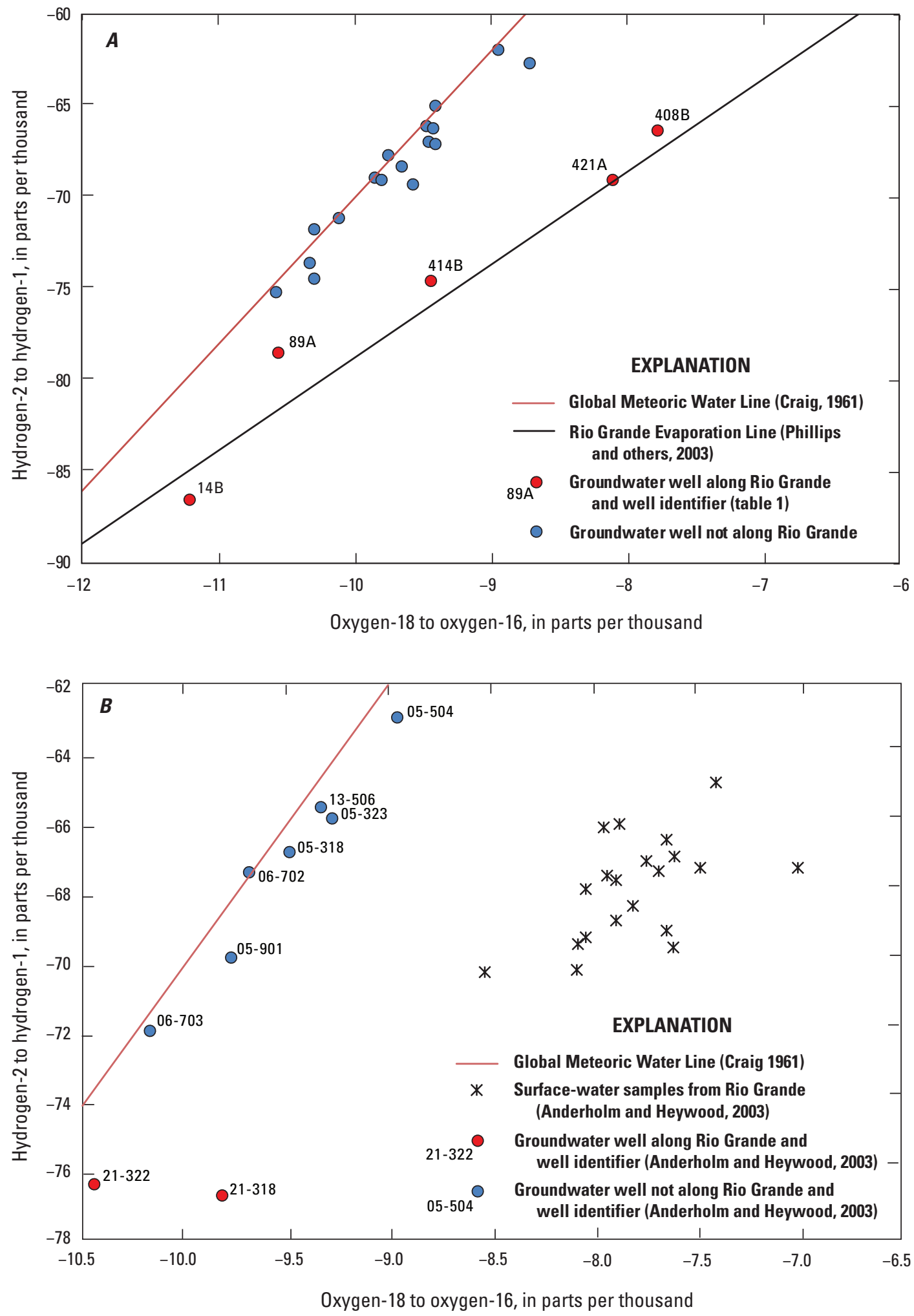

Figure 12. $A$, The ratio of oxygen-18 to oxygen-16 (delta oxygen-18) and the ratio of hydrogen-2 to hydrogen-1 (delta deuterium) measured in samples collected from wells in New Mexico and Texas in the Hueco Bolson study area, 2016-17; and $B$, the ratio of oxygen-18 to oxygen-16 (delta oxygen-18) and the ratio of hydrogen-2 to hydrogen-1 (delta deuterium) as reported in previous studies describing groundwater samples collected in the southwestern Hueco Bolson. Modified from Anderholm and Heywood (2003). 


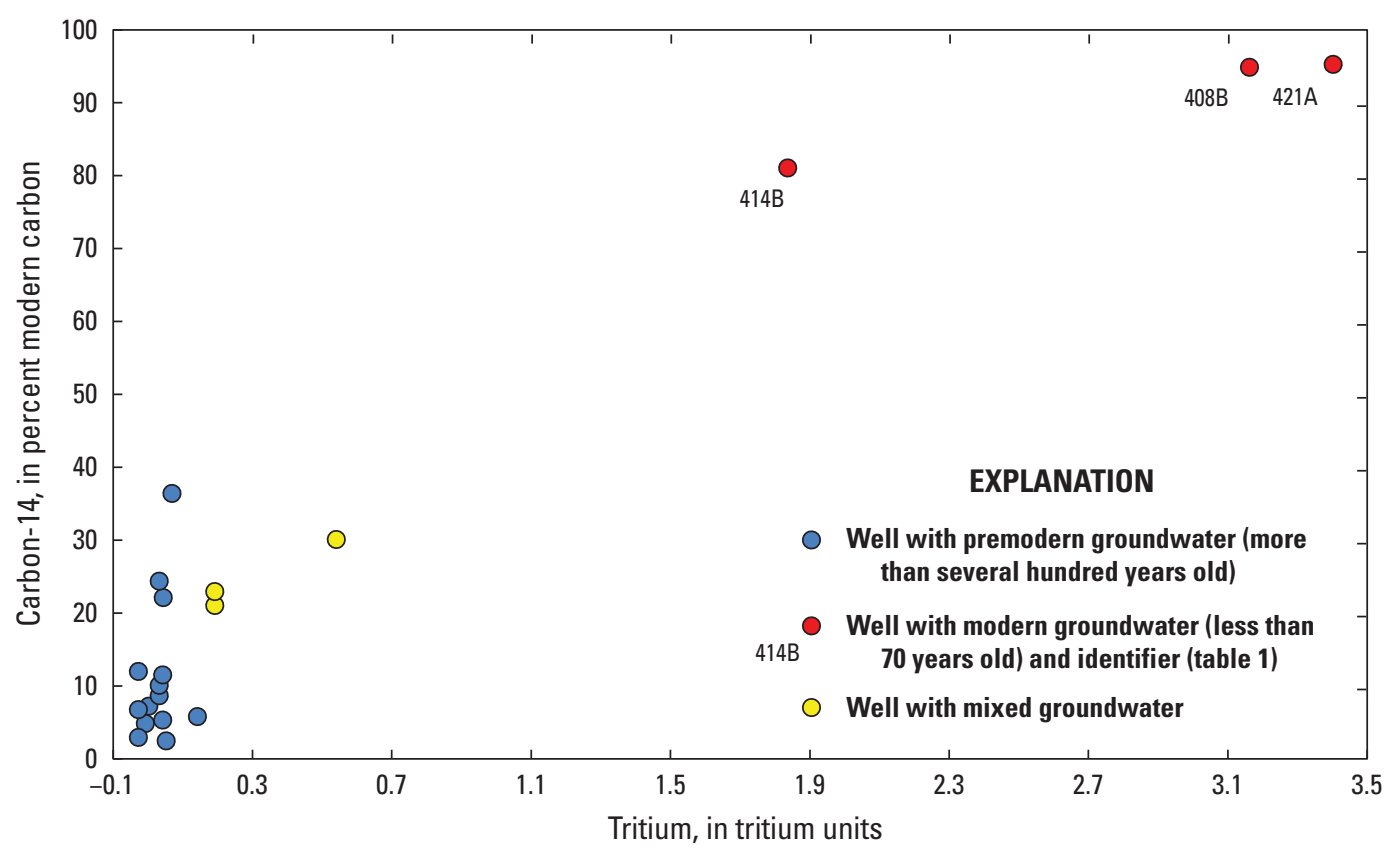

Figure 13. Carbon-14 and tritium concentrations, with apparent age designations for groundwater samples collected from wells in New Mexico and Texas in the Hueco Bolson study area, 2016-17.

By combining the results from ${ }^{3} \mathrm{H}$ and ${ }^{14} \mathrm{C}$ analyses in water samples and the spatial and temporal variability of ${ }^{3} \mathrm{H}$ deposition in precipitation, an apparent age can be assigned to the water from a given well (Michel and others, 2018; Lindsey and others, 2019; figs. 13 and 14). Water that has ${ }^{3} \mathrm{H}$ concentrations greater than $1.5 \mathrm{TU}$ is considered modern and is less than about 70 years old. Water that has ${ }^{14} \mathrm{C}$ concentrations less than $60 \mathrm{pmc}$ is considered premodern and is more than several hundred years old. Water with ${ }^{3} \mathrm{H}$ concentrations lower than $1.5 \mathrm{TU}$ and ${ }^{14} \mathrm{C}$ concentrations less than $60 \mathrm{pmc}$ is considered mixed for age-determination purposes and is considered to be a mixture of water less than about 70 years old and water more than several hundred years old (Lindsey and others, 2019). By using these classifications, 17 of the 23 groundwater samples from the study area are considered premodern (fig. 14). Wells 408B, 421A, and 414B have relatively young, or modernage, groundwater. These three wells are located near the Rio Grande and are the same wells from which samples with concentrations of arsenic or uranium of $10 \mu \mathrm{g} / \mathrm{L}$ or greater and with detections of selected organic compounds were collected (figs. 8, 9, 10, and 14). The modern groundwater and the presence of organic compounds detected in wells near the Rio Grande support potential effects of surrounding land-use activities on groundwater quality in the Rio Grande valley. 


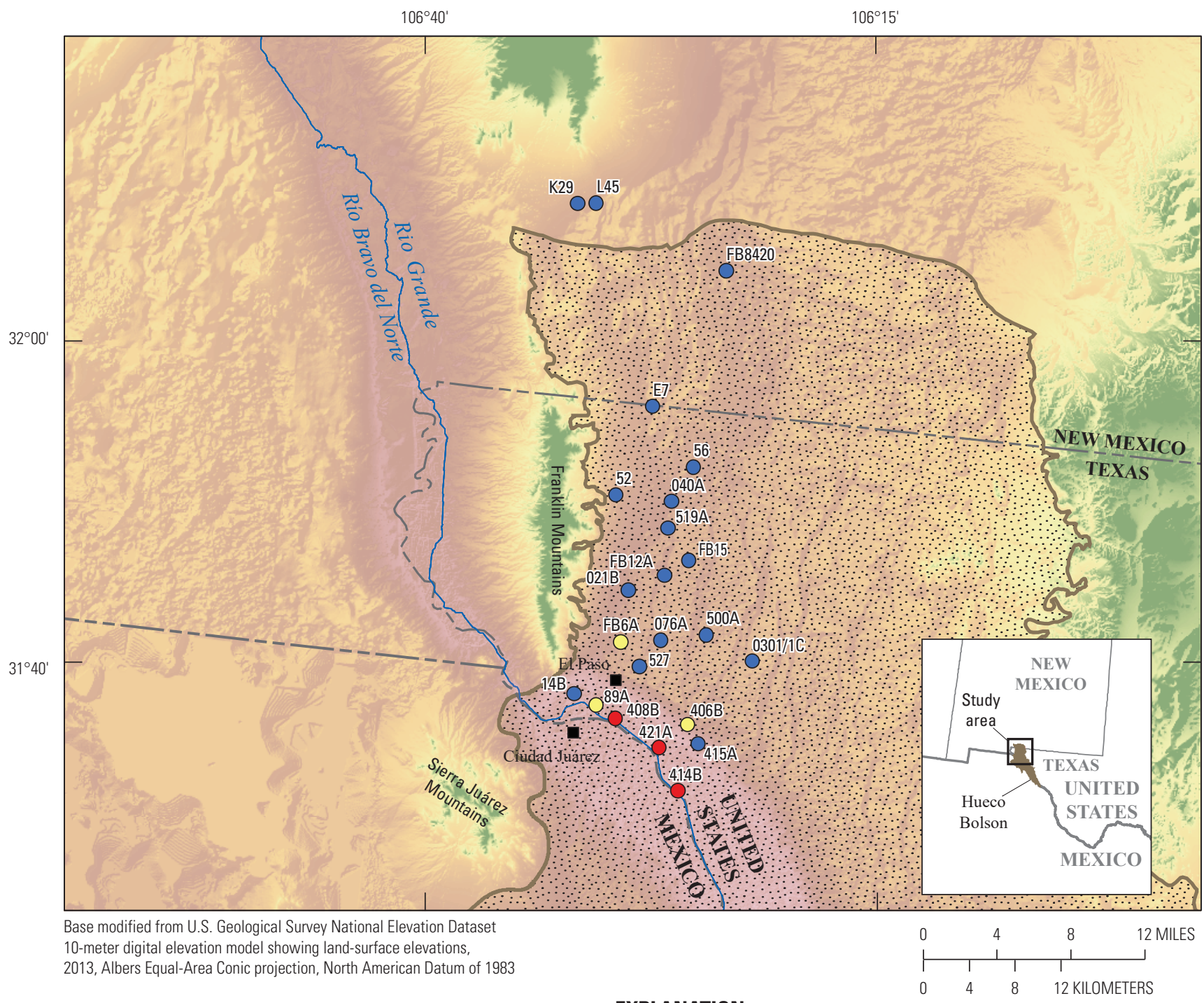

EXPLANATION

\begin{tabular}{|c|c|c|}
\hline \multirow{2}{*}{$\begin{array}{l}\text { Altitude, in feet above North } \\
\text { American Vertical Datum } \\
\text { of } 1988\end{array}$} & & Hueco Bolson \\
\hline & $415 A_{0}$ & Well with premodern groundwa \\
\hline $\begin{array}{l}2,000 \\
1,500\end{array}$ & & $\begin{array}{l}\text { (more than several hundred y } \\
\text { old) and identifier (table 1) }\end{array}$ \\
\hline $\begin{array}{l}1,000 \\
500\end{array}$ & ${ }^{414 B} \bigcirc$ & $\begin{array}{l}\text { Well with modern groundwater } \\
\text { (less than } 70 \text { years old) and } \\
\text { identifier (table 1) }\end{array}$ \\
\hline & & $\begin{array}{l}\text { Well with mixed groundwater } \\
\text { and identifier (table 1) }\end{array}$ \\
\hline
\end{tabular}

Figure 14. Relative groundwater ages for groundwater samples collected from wells in New Mexico and Texas in the Hueco Bolson study area, 2016-17. 


\section{Summary}

Twenty-three water-supply wells were sampled in the southern part of New Mexico and western part of Texas for a geochemical assessment of the Hueco Bolson. Water-quality samples from the wells were analyzed for physical properties, major ions, dissolved solids, nutrients, trace elements, organic compounds, and environmental tracers. The environmental tracers included selected isotopes such as strontium, hydrogen, oxygen, tritium, and carbon-14 to help understand potential sources and ages of the water sampled in the wells.

Most of the water samples from the Hueco Bolson wells were classified as sodium-chloride type water. Dissolvedsolids concentrations are a measure of how much dissolved constituents such as sodium and chloride are in a sample. Dissolved-solids concentrations greater than 1,000 milligrams per liter $(\mathrm{mg} / \mathrm{L})$ (which classifies water as brackish) were measured in samples collected only from four wells in the study area. Three of the four wells from which samples with the highest dissolved-solids concentrations were measured were near the Rio Grande. Dissolved-solids concentrations in groundwater also decreased with increasing well depth below land surface. This unusual pattern of decreasing dissolvedsolids concentrations with increasing well depth is probably a function of the spatial distribution of the wells, where the shallower wells with the higher dissolved-solids concentrations are the wells closest to the Rio Grande. A large coefficient of determination for a regression line fitted to the sodium and dissolved-solids concentrations indicates that sodium concentrations increase with increasing dissolved-solids concentrations; this relation is consistent with sodium being a large component of the dissolved-solids concentration.

Nitrate concentrations in the groundwater samples collected in the study area ranged from below the long-term method detection level of $0.04 \mathrm{mg} / \mathrm{L}$ to $6.2 \mathrm{mg} / \mathrm{L}$ with nitrate concentrations increasing with increasing dissolved-oxygen concentrations.

Of all trace elements measured in the groundwater samples obtained in this study, only arsenic concentrations exceeded U.S. Environmental Protection Agency drinkingwater standard of 10 micrograms per liter $(\mu \mathrm{g} / \mathrm{L})$ in samples obtained from 4 of 23 wells (17 percent); these 4 wells were located near the Rio Grande. Three of the wells where samples with the highest uranium concentrations (greater than $10 \mu \mathrm{g} / \mathrm{L}$ ) measured were also near the Rio Grande, and two of those wells were the same wells from which samples with high arsenic concentrations were obtained. The Hueco Bolson is part of the Rio Grande aquifer system, and concentrations of arsenic and uranium exceeding $5 \mu \mathrm{g} / \mathrm{L}$ have been measured in groundwater of the Rio Grande aquifer system. In addition, arsenic and uranium have frequently been detected in surfacewater samples collected from the Rio Grande upstream from Ciudad Juárez, Mexico, and El Paso, Texas, which could indicate that these trace elements are being transported downstream because arsenic and uranium are soluble in oxygen-rich environments such as surface water.
Groundwater samples were analyzed for 83 organic compounds, and of the 23 wells sampled in this study, organic compounds were detected only in samples from 5 wells. Three of the five groundwater samples with detected amounts of organic compounds were obtained from wells near the Rio Grande; these detections may be a result of surrounding landuse activities. The organic compounds that were detected in samples in this study were simazine, prometryn, prometon, atrazine, deethylatrazine, and 3,4-dichloroaniline. Multiple organic compounds are often detected in the samples collected from a single well; multiple detections of organic compounds were measured in the samples collected from four of the five of the wells with detected amounts of any organic compounds.

Environmental tracers, such as strontium isotopic ratio (strontium-87 to strontium-86, commonly expressed as $\left.{ }^{87} \mathrm{Sr} / 86 \mathrm{Sr}\right)$, hydrogen and oxygen isotopic ratio $\left(\delta \mathrm{D}\right.$ to $\left.\delta^{18} \mathrm{O}\right)$, tritium $\left({ }^{3} \mathrm{H}\right)$, and carbon- $14\left({ }^{14} \mathrm{C}\right)$ concentrations in groundwater, were analyzed in groundwater samples in this study to help with understanding where and when groundwater recharge occurred in the aquifer system. ${ }^{87} \mathrm{Sr} /{ }^{86} \mathrm{Sr}$ is useful in describing the source of groundwater and possible mixing of source waters. The ${ }^{87} \mathrm{Sr} / 86 \mathrm{Sr}$ values in five wells near the Rio Grande are similar to the mean ${ }^{87} \mathrm{Sr} / 86 \mathrm{Sr}$ value for groundwater samples collected from the Rio Grande alluvium in a groundwater study in the Mesilla Basin. In addition, ${ }^{87} \mathrm{Sr} / 86 \mathrm{Sr}$ values were slightly higher in groundwater samples collected from six wells in the central and northern part of study area, east of the Franklin Mountains, compared to ${ }^{87} \mathrm{Sr} / 86 \mathrm{Sr}$ values measured in groundwater samples collected from wells near the Rio Grande. In the same groundwater study in the Mesilla Basin, similar ${ }^{87} \mathrm{Sr} / 86 \mathrm{Sr}$ values were reported for groundwater samples from the Mesilla Basin near the Franklin Mountains. Comparison of the ratio of $\delta \mathrm{D}$ to $\delta^{18} \mathrm{O}$ values measured in groundwater samples collected in the study area to the Global Meteoric Water Line (GMWL) can help determine changes to groundwater chemistry from precipitation seeping into the aquifer. Most of the $\delta \mathrm{D}$ to $\delta^{18} \mathrm{O}$ ratios for the groundwater samples collected during this study plot near the GMWL. The $\delta \mathrm{D}$ to $\delta^{18} \mathrm{O}$ ratios for five samples collected from wells near the Rio Grande plotted below the GMWL and were similar to $\delta \mathrm{D}$ to $\delta^{18} \mathrm{O}$ ratios reported in previous studies describing groundwater samples collected from wells near the Rio Grande. The pattern of $\delta \mathrm{D}$ to $\delta^{18} \mathrm{O}$ ratios plotting below the GMWL indicates that the source of recharge for the wells along the Rio Grande is likely different from the source of recharge for the rest of the wells in the study area. This finding is consistent with the recharge information interpreted from differences in ${ }^{87} \mathrm{Sr} /{ }^{86} \mathrm{Sr}$ values.

By combining the results from ${ }^{3} \mathrm{H}$ and ${ }^{14} \mathrm{C}$ analyses in groundwater samples for this study, an apparent age can be assigned to the water from a given well. Most of the groundwater samples (17 of the 23) in the study area are considered premodern, which means that the water is more than several hundred years old. Three wells with relatively young, or modern-age, groundwater are located near the Rio Grande. Groundwater samples containing arsenic or uranium 
concentrations of $10 \mu \mathrm{g} / \mathrm{L}$ or greater were collected from these three wells, along with detections of selected organic compounds. All the environmental tracer results indicate that recharge water to wells closer to the Rio Grande is different from the recharge water to the rest of the wells in the study area.

\section{References Cited}

Abeyta, C.G., 1996, Geohydrologic site characterization of the municipal solid waste landfill facility, U.S. Army Air Defense Artillery Center and Fort Bliss, El Paso County, Texas: U.S. Geological Survey WaterResources Investigations Report 95-4217, 36 p., accessed December 18, 2019, at https://doi.org/10.3133/wri954217.

Abeyta, C.G., and Thomas, C.L., 1996, Hydrogeology and ground-water quality of the Chromic Acid Pit site, U.S. Army Air Defense Artillery Center and Fort Bliss, El Paso, Texas: U.S. Geological Survey WaterResources Investigations Report 96-4035, 67 p., accessed December 18, 2019, at https://doi.org/10.3133/wri964035.

Alley, W.M., ed., 2013, Five-year interim report of the United States-Mexico Transboundary Aquifer Assessment Program-2007-2012: U.S. Geological Survey Open-File Report 2013-1059, 31 p., accessed December 18, 2019, at https://doi.org/10.3133/ofr20131059.

Anderholm, S.K., and Heywood, C.E., 2003, Chemistry and age of ground water in the southwestern Hueco Bolson, New Mexico and Texas: U.S. Geological Survey WaterResources Investigations Report 02-4237, 16 p., accessed December 18, 2019, at https://doi.org/10.3133/wri024237.

Ayotte, J.D., Gronberg, J.M., and Apodaca, L.E., 2011, Trace elements and radon in groundwater across the United States, 1992-2003: U.S. Geological Survey Scientific Investigations Report 2011-5059, 115 p. [Also available at https://doi.org/10.3133/sir20115059.]

Banner, J.L., 2004, Radiogenic isotopes-Systematics and applications to earth surface processes and chemical stratigraphy: Earth-Science Reviews, v. 65, no. 3-4, p. 141-194, accessed December 18, 2019, at https://doi.org/10.1016/ S0012-8252(03)00086-2.

Banner, J.L., Musgrove, M., and Capo, R.C., 1994, Tracing groundwater evolution in a limestone aquifer using $\mathrm{Sr}$ isotopes-Effects of multiple sources of dissolved ions and mineral-solution reactions: Geology, v. 22, no. 8 , p. 687-690, accessed December 18, 2019, at https://doi.org/ 10.1130/0091-7613(1994)022<0687:TGWEIA>2.3.CO;2.
Bumgarner, J.R., Stanton, G.P., Teeple, A.P., Thomas, J.V., Houston, N.A., Payne, J.D., and Musgrove, M., 2012, A conceptual model of the hydrogeologic framework, geochemistry, and groundwater-flow system of the EdwardsTrinity and related aquifers in the Pecos County region, Texas: U.S. Geological Survey Scientific Investigations Report 2012-5124 (revised July 10, 2012), 74 p., accessed December 18, 2019, at https://doi.org/10.3133/sir20125124.

Buszka, P.M., Brock, R.D., and Hooper, R.P., 1994, Hydrogeology and selected water-quality aspects of the Hueco Bolson aquifer at the Hueco Bolson Recharge Project area, El Paso, Texas: U.S. Geological Survey WaterResources Investigations Report 94-4092, 41 p., accessed December 18, 2019, at https://doi.org/10.3133/wri944092.

Childress, C.J.O., Forman, W.T., Connor, B.F., and Maloney, T.J., 1999, New reporting procedures based on long-term method detection levels and some considerations for interpretations of water-quality data provided by the U.S. Geological Survey National Water Quality Laboratory: U.S. Geological Survey Open-File Report 99-193, 19 p., accessed December 18, 2019, at https://doi.org/10.3133/ ofr99193.

Clark, I.D., and Fritz, P., 1997, Environmental isotopes in hydrogeology: Boca Raton, Fla., Lewis Publishers, 328 p.

Craig, H., 1961, Isotopic variations in meteoric waters: Science, v. 133, no. 3465, p. 1702-1703, accessed December 18, 2019, at https://doi.org/10.1126/ science.133.3465.1702.

Dewitz, J., 2019, National Land Cover Database (NLCD) 2016 Products: U.S. Geological Survey data release, accessed April 9, 2020, at https://doi.org/10.5066/ P96HHBIE.

Dubrovsky, N.M., Burow, K.R., Clark, G.M., Gronberg, J.M., Hamilton, P.A., Hitt, K.J., Mueller, D.K., Munn, M.D., Nolan, B.T., Puckett, L.J., Rupert, M.G., Short, T.M., Spahr, N.E., Sprague, L.A., and Wilber, W.G., 2010, The quality of our Nation's waters-Nutrients in the Nation's streams and groundwater, 1992-2004: U.S. Geological Survey Circular 1350, 174 p. [Also available at https://doi.org/10.3133/ cir1350.]

Eastoe, C.J., Hibbs, B.J., Olivas, A.G., Hogan, J.F., Hawley, J.W., and Hutchison, W.R., 2008, Isotopes in the Hueco Bolson aquifer, Texas (USA) and Chihuahua (Mexico) Local and general implications for recharge sources in alluvial basins: Hydrogeology Journal, v. 16, no. 4, p. 737-747, accessed November 6, 2019, at https://doi.org/10.1007/ s10040-007-0247-0.

Faure, G., 1986, Principles of isotope geology: New York, Wiley, 589 p. 
Fishman, M.J., ed., 1993, Methods of analysis by the U.S. Geological Survey National Water Quality LaboratoryDetermination of inorganic and organic constituents in water and fluvial sediments: U.S. Geological Survey OpenFile Report 93-125, 217 p., accessed December 18, 2019, at https://doi.org/10.3133/ofr93125.

Fishman, M.J., and Friedman, L.C., 1989, Methods for determination of inorganic substances in water and fluvial sediments: U.S. Geological Survey Techniques of Water-Resources Investigations, book 5, chap. A1, 545 p., accessed December 18, 2019, at https://doi.org/10.3133/ twri05A1.

Fontes, J., 1980, Environmental isotopes in groundwater hydrology, in Fritz, P., and Fontes, J., Handbook of environmental isotope geochemistry, v. 1, The terrestrial environment: New York, Elsevier, p. 75-140. [Also available at https://doi.org/10.1016/B978-0-444-41780-0.50009-2]

Frenzel, P.F., and Abeyta, C.G., 1999, Geohydrology of the unsaturated zone and simulated time of arrival of landfill leachate at the water table, municipal solid waste landfill facility, U.S. Army Air Defense Artillery Center and Fort Bliss, El Paso County, Texas: U.S. Geological Survey Water-Resources Investigations Report 97-4036, 26 p.

Garbarino, J.R., 1999, Methods of analysis by the U.S. Geological Survey National Water Quality LaboratoryDetermination of dissolved arsenic, boron, lithium, selenium, strontium, thallium, and vanadium using inductively coupled plasma-mass spectrometry: U.S. Geological Survey Open-File Report 99-093, 31 p. [Also available at https://doi.org/10.3133/ofr9993.]

Garbarino, J.R., Kanagy, L.K., and Cree, M.E., 2006, Determination of elements in natural-water, biota, sediment and soil samples using collision/reaction cell inductively coupled plasma-mass spectrometry: U.S. Geological Survey Techniques and Methods, book 5, sec. B, chap. 1, 88 p., accessed December 18, 2019, at https://doi.org/10.3133/ ofr9993.

George, P.G., Mace, R.E., and Petrossian, R., 2011, Aquifers of Texas: Texas Water Development Board Report $380,172 \mathrm{p}$.

Ging, P.B., Humberson, D.G., and Langhorst, M., 2019, Transboundary Aquifer Assessment Program-Waterquality data from groundwater wells in the Hueco Bolson near El Paso, Texas, August 2016-June 2017: U.S. Geological Survey data release, accessed December 18, 2019, at https://doi.org/10.5066/F73T9GHR.

Helsel, D.R., and Hirsch, R.M., 2002, Statistical methods in water resource: U.S. Geological Survey Techniques of Water-Resources Investigations, book 4, chap. A3, 510 p., accessed September 16, 2016, at https://doi.org/10.3133/ twri04A3.
Hem, J.D., 1985, Study and interpretation of the chemical characteristics of natural water (3d ed.): U.S. Geological Survey Water-Supply Paper 2254, 263 p., accessed December 18, 2019, at https://doi.org/10.3133/wsp2254.

Heywood, C.E., and Yager, R.M., 2003, Simulated groundwater flow in the Hueco Bolson, an alluvial-basin aquifer system near El Paso, Texas: U.S. Geological Survey WaterResources Investigations Report 02-4108, 73 p., accessed December 18, 2019, at https://doi.org/10.3133/wri024108.

Hibbs, B.J., 1999, Hydrogeologic and water quality issues along the El Paso/Juárez Corridor-An International Case Study: Environmental \& Engineering Geoscience, v. V, no. 1, p. 27-39, accessed December 18, 2019, at https://doi.org/10.2113/gseegeosci.V.1.27.

Hinkle, S.R., 1996, Age of ground water in basalt aquifers near Spring Creek National Fish Hatchery, Skamania County, Washington: U.S. Geological Survey WaterResources Investigations Report 95-4272, 26 p., accessed December 18, 2019, at https://doi.org/10.3133/wri954272.

Horowitz, A.J., Lum, K.R., Garbarino, J.R., Hall, G.E.M., LeMieux, C., and Demas, C.R., 1996, Problems associated with using filtration to define dissolved trace element concentrations in natural water samples: Environmental Science \& Technology, v. 30, no. 3, p. 954-963, accessed December 18, 2019, at https://doi.org/10.1021/es950407h.

Hutchison, W.R., 2006, Groundwater management in El Paso, Texas: University of Texas at El Paso, Ph.D. dissertation, 329 p., accessed February 5, 2020, at http://www.bookpump.com/dps/pdf-b/1123280b.pdf.

Hutchison, W.R., and Hibbs, B.J., 2008, Ground water budget analysis and cross-formational leakage in an arid basin: Ground Water, v. 46, no. 3, p. 384-395, accessed December 18, 2019, at https://doi.org/10.1111/j.17456584.2008.00446.x.

Ingebritsen, S.E., and Sanford, W.E., 1999, Groundwater in geologic processes ( $2 \mathrm{~d}$ ed.): New York, Cambridge University Press, $341 \mathrm{p}$.

Kalin, R.M., 2000, Radiocarbon dating of groundwater systems, in Cook, P.G., and Herczeg, A.L., eds., Chapter 4-Environmental tracers in subsurface hydrology: Boston, Kluwer Academic Publishers, p. 111-144, accessed December 18, 2019, at https://doi.org/10.1007/978-1-46154557-6 4.

Karlen, I., Olsson, I.U., Kallburg, P., and Kilici, S., 1964, Absolute determination of the activity of two ${ }^{14} \mathrm{C}$ dating standards: Arkiv Geofysik, v. 4, p. 465-471. 
Kendall, C., and McDonnell, J.J., 1998, Isotope tracers in catchment hydrology-Fundamentals of isotope geochemistry: Amsterdam, Elsevier, p. 51-86. [Also available at https://doi.org/10.1016/B978-0-444-81546-0.50009-4.]

Koterba, M.T., Wilde, F.D., and Lapham, W.W., 1995, Groundwater data-collection protocols and procedures for the National Water-Quality Assessment ProgramCollection and documentation of water-quality samples and related data: U.S. Geological Survey Open-File Report 95-399, 113 p. [Also available at https://doi.org/10.3133/ ofr95399.]

Lemay, T.G., 2002, Carbon-14 dating of groundwater from selected wells in Quaternary and Quaternary-Tertiary sediments, Athabasca Oil Sands (in-situ) area, Alberta: Alberta Geological Survey, $21 \mathrm{p}$.

Levings, G.W., Healy, D.F., Richey, S.F., and Carter, L.F., 1998, Water quality in the Rio Grande Valley, Colorado, New Mexico, and Texas, 1992-95: U.S. Geological Survey Circular 1162, 39 p., accessed February 4, 2020, at https://doi.org/10.3133/cir1162.

Libby, W.F., 1955, Radiocarbon dating (2d ed.): Chicago, University of Chicago Press, 175 p.

Lindley, C.E., Stewart, J.T., and Sandstrom, M.W., 1996, Determination of low concentrations of acetochlor in water by automated solid-phase extraction and gas chromatography with mass selective detection: Journal of AOAC International, v. 79, no. 4, p. 962-966. [Also available at https://doi.org/10.1093/jaoac/79.4.962.]

Lindsey, B.D., Jurgens, B.C., and Belitz, K., 2019, Tritium as an indicator of modern, mixed, and premodern groundwater age: U.S. Geological Survey Scientific Investigations Report 2019-5090, 18 p., accessed December 18, 2019, at https://doi.org/10.3133/sir20195090.

Linsley, R.K., Kohler, M.A., and Paulhus, J.L.H., 1982, Hydrology for engineers ( $3 \mathrm{~d}$ ed.): New York, McGrawHill, 512 p.

Lucas, L.L., and Unterweger, M.P., 2000, Comprehensive review and critical evaluation of the half-life of tritium: Journal of Research of the National Institute of Standards and Technology, v. 105, no. 4, p. 541-549, accessed December 18, 2019, at https://doi.org/ $10.6028 \% 2$ Fjres. 105.043 .

Lurry, D.L., Reutter, D.C., and Wells, F.C., 1998, Monitoring the water quality of the Nation's large rivers - Rio Grande NASQAN Program: U.S. Geological Survey Fact Sheet 083-98, 2 p., accessed December 18, 2019, at https://doi.org/10.3133/fs08398.
Madsen, J.E., Sandstrom, M.W., and Zaugg, S.D., 2003, Methods of analysis by the U.S. Geological Survey National Water Quality Laboratory-A method supplement for the determination of fipronil and degradates in water by gas chromatography/mass spectrometry: U.S. Geological Survey Open-File Report 02-462, 11 p., accessed December 18, 2019, at https://doi.org/10.3133/ofr02462.

Martin, J.D., Stone, W.W., Wydoski, D.S., and Sandstrom, M.W., 2009, Adjustment of pesticide concentrations for temporal changes in analytical recovery, 1992-2006: U.S. Geological Survey Scientific Investigations Report 2009-5189, 23 p. plus appendixes, accessed December 18, 2019, at https://doi.org/10.3133/sir20095189.

McNutt, R., Frape, S.K., Fritz, P., Jones, M.G., and MacDonald, I.M., 1990, The ${ }^{87} \mathrm{Sr}-86 \mathrm{Sr}$ values of Canadian Shield brines and fracture minerals with applications to groundwater mixing, fracture history, and geochronology: Geochimica et Cosmochimica Acta, v. 54, no. 1, p. 205-215, accessed December 18, 2019, at https://doi.org/ 10.1016/0016-7037(90)90208-3.

Menheer, M.A., and Brigham, M.E., 1997, Ground-water sampling methods and quality-control data for the Red River of the North Basin, Minnesota, North Dakota, and South Dakota, 1993-95: U.S. Geological Survey WaterResources Investigations Report 96-4317, 34 p., accessed December 18, 2019, at https://doi.org/10.3133/wri964317.

Michel, R.L., Jurgens, B.C., and Young, M.B., 2018, Tritium deposition in precipitation in the United States, 1953-2012: U.S. Geological Survey Scientific Investigations Report 2018-5086, 11 p., accessed December 18, 2019, at https://doi.org/10.3133/sir20185086.

Motzer, W.E., 2008, Age dating groundwater: Todd Engineers, 4 p.

Mueller, D.K., Martin, J.D., and Lopes, T.J., 1997, Qualitycontrol design of surface-water sampling in the National Water-Quality Assessment Program: U.S. Geological Survey Open-File Report 97-223, 17 p. [Also available at https://doi.org/10.3133/ofr97223.]

Mueller, D.K., Schertz, T.L., Martin, J.D., and Sandstrom, M.W., 2015, Design, analysis, and interpretation of field quality-control data for water-sampling projects: U.S. Geological Survey Techniques and Methods, book 4, chap. C4, 54 p., accessed December 18, 2019, at https://doi.org/10.3133/tm4C4.

Musgrove, M., and Banner, J.L., 1993, Regional groundwater mixing and the origin of saline fluids-Midcontinent, United States: Science, v. 259, no. 5103, p. 1877-1882, accessed December 18, 2019, at https://doi.org/10.1126/ science.259.5103.1877. 
Musgrove, M., and Bexfield, L.M., 2017, Groundwater quality in the Rio Grande aquifer system, southwestern United States: U.S. Geological Survey Fact Sheet 2017-3047, 4 p., accessed December 18, 2019, at https://doi.org/10.3133/ fs20173047.

Musgrove, M., Fahlquist, L., Houston, N.A., Lindgren, R.J., and Ging, P.B., 2010, Geochemical evolution processes and water-quality observations based on results of the National Water-Quality Assessment Program in the San Antonio segment of the Edwards aquifer, 1996-2006: U.S. Geological Survey Scientific Investigations Report 2010-5129, 93 p., accessed December 18, 2019, at https://doi.org/10.3133/ $\operatorname{sir} 20105129$.

National Aeronautics and Space Administration, 2014, Earth Observatory, El Paso and Ciudad Juárez, accessed December 18, 2019, at https://earthobservatory.nasa.gov/ images/84692/el-paso-and-ciudad-juarez.

Neuendorf, K.K.E., Mehl, J.P., Jr., and Jackson, J.A., eds., 2005, Glossary of geology (5th ed.): Alexandria, Va., American Geological Institute, 779 p.

Nishikawa, T., Izbicki, J.A., Hevesi, J.A., Stamos, C.L., and Martin, P., 2004, Evaluation of geohydrologic framework, recharge estimates, and ground-water flow of the Joshua Tree area, San Bernardino County, California: U.S. Geological Survey Scientific Investigations Report 2004-5267, 115 p., accessed December 18, 2019, at https://doi.org/10.3133/sir20045267.

Oden, J.H., Brown, D.W., and Oden, T.D., 2011, Groundwater quality of the Gulf Coast aquifer system, Houston, Texas, 2010: U.S. Geological Survey Data Series 598, 64 p., accessed December 18, 2019, at https://doi.org/10.3133/ ds598.

Oden, T.D., and Truini, M., 2013, Estimated rates of groundwater recharge to the Chicot, Evangeline, and Jasper aquifers by using environmental tracers in Montgomery and adjacent counties, Texas, 2008 and 2011: U.S. Geological Survey Scientific Investigations Report 2013-5024, 50 p., accessed December 18, 2019, at https://doi.org/10.3133/ $\operatorname{sir} 20135024$.

Olsson, I.U., and Klasson, M., 1970, Uppsala radiocarbon measurements X: Radiocarbon, v. 12, no. 1, p. 281-284, accessed December 18, 2019, at https://doi.org/10.1017/ S0033822200036328.

Orr, B.R., and Risser, D.W., 1992, Geohydrology and potential effects of development of freshwater resources in the northern part of the Hueco Bolson, Dona Ana and Otero Counties, New Mexico, and El Paso County, Texas: U.S. Geological Survey Water-Resources Investigations Report 91-4082, 42 p., accessed December 18, 2019, at https://doi.org/10.3133/wri914082.
Östlund, H.G., and Werner, E., 1962, Electrolytic enrichment of tritium and deuterium for natural tritium measurementsTritium in the physical and biological sciences v. 1: Vienna, Austria, International Atomic Energy Agency, p. 96-104.

Patton, C.J., and Kryskalla, J.R., 2003, Methods of analysis by the U.S. Geological Survey National Water Quality Laboratory-Evaluation of alkaline persulfate digestion as an alternative to kjeldahl digestion for determination of total and dissolved nitrogen and phosphorus in water: U.S. Geological Survey Water-Resources Investigations Report 03-4174, 33 p., accessed December 18, 2019, at https://doi.org/10.3133/wri034174.

Patton, C.J., and Truitt, E.P., 2000, Methods of analysis by the U.S. Geological Survey National Water Quality Laboratory-Determination of ammonium plus organic nitrogen by a Kjeldahl digestion method and an automated photometric finish that includes digest cleanup by gas diffusion: U.S. Geological Survey Open-File Report 00-170, 31 p., accessed December 18, 2019, at https://doi.org/ $10.3133 /$ ofr00170.

Phillips, F.M., and Castro, M.C., 2003, Groundwater dating and residence-time measurements, in Drever, J.I., ed., 2005, Surface and ground water, weathering, and soils-Treatise on geochemistry: Boston, Elsevier, p. 451-497.

Phillips, F.M., Mills, S., Hendrickx, J.M.H., and Hogan, J., 2003, Environmental tracers applied to quantifying causes of salinity in arid-region rivers-Results from the Rio Grande Basin, Southwestern USA: Developments in Water Science, v. 50, p. 327-334, accessed December 18, 2019, at https://doi.org/10.1016/S0167-5648(03)80029-1.

Piper, A.M., 1944, A graphic procedure in the geochemical interpretation of water analyses: Transactions American Geophysical Union, v. 25, no. 6, p. 914-923, accessed December 18, 2019, at https://doi.org/10.1029/ TR025i006p00914.

Plummer, L.N., Bexfield, L.M., Anderholm, S.K., Sanford, W.E., and Busenberg, E., 2004, Geochemical characterization of ground-water flow in the Santa Fe Group aquifer system, Middle Rio Grande Basin, New Mexico: U.S. Geological Survey Water-Resources Investigations Report 03-4131, 414 p., accessed December 18, 2019, at https://doi.org/10.3133/wri034131.

Plummer, L.N., and Busenberg, E., 2000, Chlorofluorocarbons, chap. 15 of Cook, P.G., and Herczeg, A.L., eds., Environmental tracers in subsurface hydrology: Boston, Mass., Kluwer Academic Press, p. 441-478. [Also available at https://doi.org/10.1007/978-1-4615-4557-6_15.] 
Plummer, L.N., Prestemon, E.C., and Parkhurst, D.L., 1994, An interactive code (NETPATH) for modeling net geochemical reactions along a flow path version 2.0: U.S. Geological Survey Water-Resources Investigations Report 94-4169, 133 p., accessed December 18, 2019, at https://doi.org/ 10.3133/wri944169.

Raymond, P.A., and Bauer, J.E., 2001, Use of ${ }^{14} \mathrm{C}$ and ${ }^{13} \mathrm{C}$ natural abundances for evaluating riverine, estuarine, and coastal DOC and POC sources and cycling - A review and synthesis: Organic Geochemistry, v. 32, no. 4, p. 469-485, accessed December 18, 2019, at https://doi.org/10.1016/ S0146-6380(00)00190-X.

Révész, K., and Coplen, T.B., 2008a, Determination of the $\delta\left({ }^{2} \mathrm{H} / 1 \mathrm{H}\right)$ of water-RSIL lab code 1574 , chap. $\mathrm{C} 1$ of Révész, Kinga, and Coplen, T.B., eds., Methods of the Reston Stable Isotope Laboratory: U.S. Geological Survey Techniques and Methods, book 10, chap. C1, 27 p., accessed December 18, 2019, at https://doi.org/10.3133/ tm10C1.

Révész, K., and Coplen, T.B., 2008b, Determination of the $\delta(180 / 160)$ of water-RSIL lab code 489 , chap. C2 of Révész, Kinga, and Coplen, T.B., eds., Methods of the Reston Stable Isotope Laboratory: U.S. Geological Survey Techniques and Methods, book 10, chap. C2, 28 p., accessed December 18, 2019, at https://doi.org/10.3133/ tm10C2.

Roberts, M.L., Burton, J.R., Elder, K.L., Longworth, B.E., McIntyre, C.P., von Reden, K.F., Han, B.X., Rosenheim, B.E., Jenkins, W.J., Galutschek, E., and McNichol, A.P., 2010, A high-performance ${ }^{14} \mathrm{C}$ accelerator mass spectrometry system: Radiocarbon, v. 52, no. 2, p. 228-235, accessed December 18, 2019, at https://doi.org/10.1017/ S0033822200045252.

Robertson, F.N., 1991, Geochemistry of ground water in alluvial basins of Arizona and adjacent parts of Nevada, New Mexico, and California: U.S. Geological Survey Professional Paper 1406-C, 90 p., accessed December 18, 2019, at https://doi.org/10.3133/pp1406C.

Sandstrom, M.W., Stroppel, M.E., Foreman, W.T., and Schroeder, M.P., 2001, Methods of analysis by the U.S. Geological Survey National Water Quality LaboratoryDetermination of moderate-use pesticides and selected degradates in water by $\mathrm{C}-18$ solid-phase extraction and gas chromatography/mass spectrometry: U.S. Geological Survey Water-Resources Investigations Report 01-4098, 70 p., accessed December 18, 2019, at https://doi.org/10.3133/ wri20014098.

Scanlon, B., Nicot, J.-P., Reedy, R., Tachovsky, J., Nance, S., Smyth, R., Keese, K., Ashburn, R., and Christian, L., 2005, Evaluation of arsenic contamination in Texas: Bureau of Economic Geology, $177 \mathrm{p}$.
Shelton, L.R., 1994, Field guide for collecting and processing stream-water samples for the National Water-Quality Assessment Program: U.S. Geological Survey Open-File Report 94-455, 42 p. [Also available at https://doi.org/ 10.3133/ofr94455.]

Sheng, Z., 2005, An aquifer storage and recovery system with reclaimed wastewater to preserve native groundwater resources in El Paso, Texas: Journal of Environmental Management, v. 75 , no. 4, p. 367-377, accessed December 18, 2019, at http://doi.org/10.1016/ j.jenvman.2004.10.007.

Shoda, M.E., Nowell, L.H., Bexfield, L.M., Sandstrom, M.W., and Stone, W.W., 2017, Recovery data for surface water, groundwater and lab reagent samples analyzed by the USGS National Water Quality Laboratory schedule 2437, water years 2013-15: U.S. Geological Survey data release, accessed December 18, 2019, at https://doi.org/10.5066/ F7QZ28G4.

Stuiver, M., 1980, Workshop on ${ }^{14} \mathrm{C}$ data reporting: Radiocarbon, v. 22, no. 3, p. 964-966, accessed December 18, 2019, at https://doi.org/10.1017/ S0033822200010389.

Stuiver, M., and Polach, H.A., 1977, Discussion reporting of ${ }^{14} \mathrm{C}$ data: Radiocarbon, v. 19, no. 3, p. 355-363, accessed December 18, 2019, at https://doi.org/10.1017/ S0033822200003672.

Struzeski, T.M., DeGiacomo, W.J., and Zayhowski, E.J., 1996, Methods of analysis by the U.S. Geological Survey National Water Quality Laboratory-Determination of dissolved aluminum and boron in water by inductively coupled plasmaatomic emission spectrometry: U.S. Geological Survey Open-File Report 96-149, 17 p., accessed December 18, 2019, at https://doi.org/10.3133/ofr96149.

Szabo, Z., dePaul, V.T., Fischer, J.M., Kraemer, T.F., and Jacobsen, E., 2012, Occurrence and geochemistry of radium in water from principal drinking-water aquifer systems of the United States: Applied Geochemistry, v. 27, no. 3, p. 729-752, accessed December 18, 2019, at https://doi.org/ 10.1016/j.apgeochem.2011.11.002.

Teeple, A.P., 2017, Geophysics- and geochemistry-based assessment of the geochemical characteristics and groundwater-flow system of the U.S. part of the Mesilla Basin/Conejos-Médanos aquifer system in Doña Ana County, New Mexico, and El Paso County, Texas, 2010-12: U.S. Geological Survey Scientific Investigations Report 2017-5028, 183 p., accessed December 10, 2019, at https://doi.org/10.3133/sir20175028. 
Thatcher, L.L., Janzer, V.J., and Edwards, K.W., 1977 , Methods for determination of radioactive substances in water and fluvial sediments: U.S. Geological Survey Techniques of Water-Resources Investigations, book 5, chap. A5, 95 p., accessed December 18, 2019, at https://doi.org/10.3133/twri05A5.

Uliana, M.M., Banner, J.L., and Sharp, J.M., Jr., 2007, Regional groundwater flow paths in Trans-Pecos, Texas inferred from oxygen, hydrogen, and strontium isotopes: Journal of Hydrology (Amsterdam), v. 334, no. 3-4, p. 334-346, accessed December 18, 2019, at https://doi.org/ 10.1016/j.jhydrol.2006.10.015.

U.S. Environmental Protection Agency [EPA], 2009, National Primary Drinking Water Regulations: EPA 816-F-09-004, 7 p., accessed December 18, 2019, at https://www.epa.gov/ sites/production/files/2016-06/documents/npwdr_complete_ table.pdf.

U.S. Geological Survey [USGS], 2019, USGS water data for the Nation: U.S. Geological Survey National Water Information System database, accessed June 1, 2019, at https://doi.org/10.5066/F7P55KJN.

U.S. Geological Survey [USGS], variously dated, National field manual for the collection of water-quality data: U.S. Geological Survey Techniques of Water-Resources Investigations, book 9, chaps. A1-A9. [Also available at https://doi.org/10.3133/twri09A.]

White, D.E., 1983, Summary of hydrologic information in the El Paso, Texas, area, with emphasis on ground-water studies, 1903-80: U.S. Geological Survey Open-File Report 83-775, 77 p., accessed December 18, 2019, at https://doi.org/10.3133/ofr83775.
White, D.E., Baker, E.T., Jr., and Sperka, R., 1997, Hydrology of the shallow aquifer and uppermost semiconfined aquifer near El Paso, Texas: U.S. Geological Survey WaterResources Investigations Report 97-4263, 37 p., accessed December 18, 2019, at https://doi.org/10.3133/wri974263.

Wilde, F.D., ed., 2004, Cleaning of equipment for water sampling (ver. 2.0): U.S. Geological Survey Techniques of Water-Resources Investigations, book 9, chap. A3, accessed September 2011 at https://doi.org/10.3133/twri09A3.

Wilde, F.D., Radtke, D.B., Gibs, J., and Iwatsubo, R.T., eds., 2004, with updates through 2009, Processing of water samples (ver. 2.2): U.S. Geological Survey Techniques of Water-Resources Investigations, book 9, chap. A5, accessed October 21, 2015, at https://doi.org/10.3133/twri09A5.

Wilkins, D.W., 1986, Geohydrology of the southwest alluvial basins regional aquifer systems analysis, parts of Colorado, New Mexico, and Texas: U.S. Geological Survey WaterResources Investigations Report 84-4224, 61 p., accessed December 18, 2019, at https://doi.org/10.3133/wri844224.

Witcher, J.C., King, J.P., Hawley, J.W., Kennedy, J.F., Williams, J., Cleary, M., and Bothern, L.R., 2004, Sources of salinity in the Rio Grande and Mesilla Basin groundwater: New Mexico Water Resources Research Institute Technical Completion Report no. 330, 184 p.

Zaugg, S.D., Sandstrom, M.W., Smith, S.G., and Fehlberg, K.M., 1995, Methods of analysis by the U.S. Geological Survey National Water Quality Laboratory-Determination of pesticides in water by C-18 solid-phase extraction and capillary-column gas chromatography/mass spectrometry with selected-ion monitoring: U.S. Geological Survey Open-File Report 95-181, 60 p. [Also available at https://doi.org/10.3133/ofr95181.] 
For more information about this publication, contact Director, Oklahoma-Texas Water Science Center U.S. Geological Survey

1505 Ferguson Lane

Austin, Texas 78754-4501

For additional information, visit https://www.usgs.gov/centers/tx-water/

Publishing support provided by Lafayette Publishing Service Center 


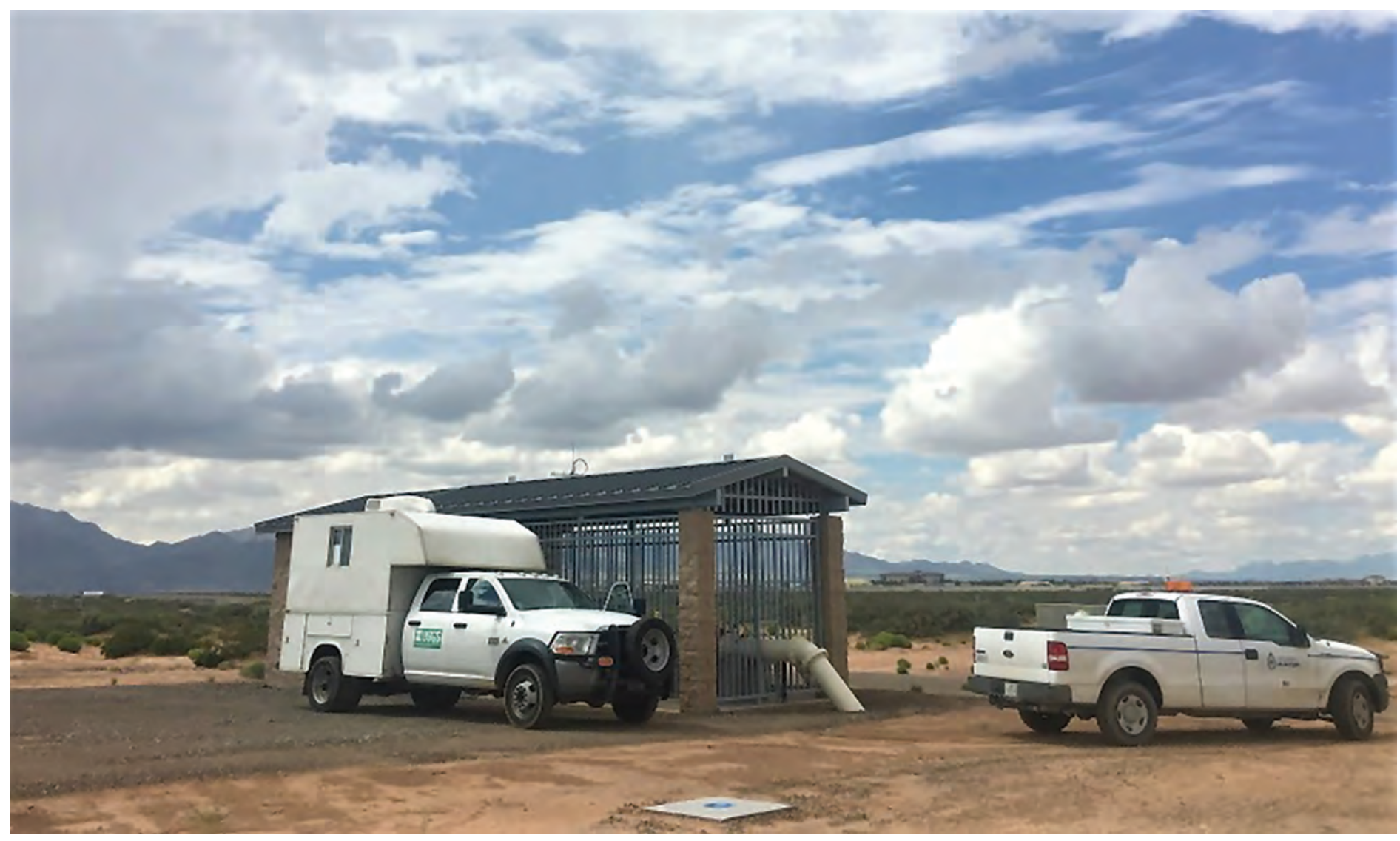

